\title{
Uma breve história de retomada: a comunidade Lago da Praia e conflitos territoriais
}

\author{
A brief history of retaking: the Lago da Praia community \\ and territorial conflicts
}

Eriki Aleixo de Melo ${ }^{1}$

DOI: http://dx.doi.org/10.20435/tellus.v0i42.677

Ali era lugar de caçar, era lugar de pescar. Ali é lugar do nosso bisavô, pai, irmão, tio, era o papai; [...] quando papai morava por aqui, era lugar de caçar para lá. Tio Conrado. Todo mundo. No Lago da Praia. Pescar no Santa Rita até na beira do rio Uraricoera. Era lugar de pescar por ali. Joãozinho morava por ali onde era Caimbezal, caçava veado. Então por isso que foi para ganhar aquele pra isso, pra caçar, pra gente caçar. (Assis Aleixo Angelo - Wapichana).

Era uma coisa assim, parece que era um sonho [risos]. (Geovânia Angelo Aleixo - Wapichana).

E é muito impossível dizer assim voltar para lá, como naquela época, né, aquela época não volta mais. Se for, vem outros. Porque a gente não teve apoio, segurança dos governantes, eles falavam uma coisa, falavam outra coisa, mas não podiam fazer nada por nós porque eles estavam, eles eram contra nós. (Gercina Angelo da Silva - Wapichana).

Resumo: Em abril de 2004, deu-se o início da comunidade indígena Lago da Praia, a partir de mobilizações étnicas dos Wapichana e Macuxi da terra indígena Serra da Moça. Sua criação esteve amplamente relacionada ao contexto conflituoso local, no qual a relação entre indígenas, fazendeiros e demais agentes foi historicamente marcada pela violência e a usurpação de seus territórios. Nesse sentido, as tensões sociais foram se agravando no decorrer dos anos, principalmente devido à conjuntura política regional, relacionada à luta pela demarcação da terra indígena Raposa/Serra do Sol e as "condicionantes" impostas pelo Supremo Tribunal Federal. Em 2009, os indígenas passaram a vivenciar diversos eventos críticos e a ser coagidos para que saíssem da comunidade, ocasionando a expulsão dos indígenas de suas casas. Em 2010, o ministro do STF Gilmar Mendes fundamentou uma

1 Universidade Federal do Amazonas (Ufam), Manaus, Amazonas, Brasil. 
ação cautelar, favorecendo o Governo do Estado de Roraima e afirmando que a referida terra indígena não poderia ser ampliada. Este artigo trata desta retomada de terra, da construção da comunidade Lago da Praia e da expulsão dos Wapichana e Macuxi.

Palavras-chave: mobilização étnica; Lago da Praia; retomada; conflitos territoriais.

\begin{abstract}
In April 2004, the Lago da Praia indigenous community started, based on ethnic mobilizations of the Wapichana and Macuxi of the Serra da Moça indigenous land. Its creation was largely related to the local conflictual context, in which the relationship between indigenous people, farmers, and other agents has historically been marked by violence and the usurpation of their territories. In this sense, social tensions have worsened over the years, mainly due to the regional political situation, related to the struggle for the demarcation of the Raposa/Serra do Sol indigenous land and the "conditions" imposed by the Brazilian Supreme Court. In 2009, the indigenous people began to experience several critical events and to be coerced to leave the community, causing the expulsion of the indigenous people from their homes. In 2010, the Supreme Court Justice Gilmar Mendes founded a Cautionary Action, favoring the Government of the State of Roraima and affirming that the referred indigenous land could not be expanded. This article deals with this land retaking, the construction of the Lago da Praia community, and the expulsion of the Wapichana and Macuxi.
\end{abstract}

Keywords: ethnic mobilization; Lago da Praia; land retakings; territorial conflicts.

\title{
1 ISTO NÃO É UMA AUTOBIOGRAFIA - À GUISA DE INTRODUÇÃO
}

Eu gostaria de iniciar este escrito me apresentado brevemente, apenas para situar de onde e o que estou falando. Não é minha intenção construir um texto autobiográfico, mas contar uma parte da história do meu povo na luta pela terra que ocorreu entre os anos de 2004, quando se iniciou uma retomada, até o ano de 2009, quando os parentes indígenas foram expulsos de suas casas na comunidade Lago da Praia. E, devido a minha participação nesta retomada, parte destes escritos são fragmentos da minha turva memória. Turva porque naquela época, com 11 anos de idade, estava cursando a quarta série do ensino fundamental na Escola Estadual Indígena José Aleixo Ângelo e não existia nenhuma pretensão de refletir criticamente sobre essas vivências.

Através deste escrito, pretendo ir um pouco além do que Castro Faria definiu como depoimento, já que "o depoimento [...] permite que a pessoa que fala 
se transfigure em testemunha. Depõe sobre acontecimentos, oferece registros" (CASTRO FARIA, 1993, p. 228). Não é somente isso. Para além de testemunhar parte dos acontecimentos ocorridos durante a retomada, meu esforço para tratar dessas memórias tampouco seria possível se eu não estivesse me valendo também da memória dos parentes que vivenciaram comigo essa luta e que, na época, tinham mais idade do que eu e viveram com maior intensidade os conflitos que se passaram. Esses parentes aqui mencionados foram os que estiveram na linha de frente no processo da retomada. São as denominadas lideranças tradicionais das nossas comunidades.

Esclareço ainda que o que for mencionado ou apresentado, tais como datas, falas, croquis de mapas e publicações de cunho oficiais, são dados levantados a partir de extensa pesquisa de campo realizada no âmbito do Projeto Nova Cartografia Social da Amazônia (PNCSA), entre os anos de 2017 e 2019, para construção de minha dissertação de Mestrado em Antropologia Social no Programa de Pós-Graduação da Ufam. Por isso, não se trata apenas de um memorialismo, até porque no meu caso, como diria novamente Castro Faria, seria "bastante pobre", mas trata-se de um esforço reflexivo sobre esses dados de campo, que muitas das vezes colocaram até dúvidas em minhas memórias e conhecimentos apriorísticos. Em consonância com a crítica à ilusão autobiográfica de Bourdieu (2002) e Castro Faria (1993), não pretendo sacrificar a reflexividade da minha pesquisa de campo ao gênero autobiográfico (ALMEIDA, 2018), mas sim entrelaçar minha memória com a memória dos que aqui contribuíram e a etnografia.

Destaco que trago como fontes os documentos que tramitaram em diversos órgãos. São ofícios, atas de reuniões, memorandos, cartas públicas, assinaturas e croquis que tratam da comunidade Lago da Praia, os quais me foram disponibilizados pela Assessora Jurídica do Conselho Indígena de Roraima (CIR), Joênia Wapichana, no ano de 2016. A maior parte dessa documentação foi utilizada relacionando as narrativas obtidas através de entrevistas com alguns moradores da referida comunidade. Foram 7 (sete) entrevistados no total, sendo 4 (quatro) mulheres e 3 (homens), todos indígenas Macuxi e Wapichana, que moraram no Lago da Praia e que, no período da entrevista, isto é, 2016, já estavam morando em suas antigas comunidades. E, como mencionei, eles estiveram na linha de frente dessa batalha. 
O meu nome é Eriki Aleixo. Na língua wapichana, como meu professor Maxi'i (Andarilho) me chamou, meu nome é Abaxiiz, que significa "orvalho", aqueles pingos de águas que amanhecem nas folhas das árvores. Pertenço ao povo Wapichana, sou morador da comunidade Serra do Truarú, que faz parte da terra indígena Serra da Moça (etnorregião Murupú). Esta terra indígena está localizada a uma distância de $60 \mathrm{~km}$ do centro urbano de Boa Vista, capital do estado de Roraima (Figura 3). Além da comunidade Serra do Truarú, fazem parte desta referida terra indígena as comunidades Morcego, Serra da Moça e, até no ano de 2009, também a comunidade Lago da Praia.

O agrupamento de determinadas terras indígenas caracteriza uma etnorregião. Essas etnorregiões são unidades que reúnem terras indígenas que compartilham elementos culturais, relacionam-se entre si territorialmente e possuem articulações políticas em comum. Desta forma, a terra indígena Serra da Moça, junto da terra indígena Anzol e terra indígena Truarú, constituem a etnorregião Murupú.

Figura 1 - Divisão territorial da Etnorregião Murupú

\section{Etnorregião Murupú}
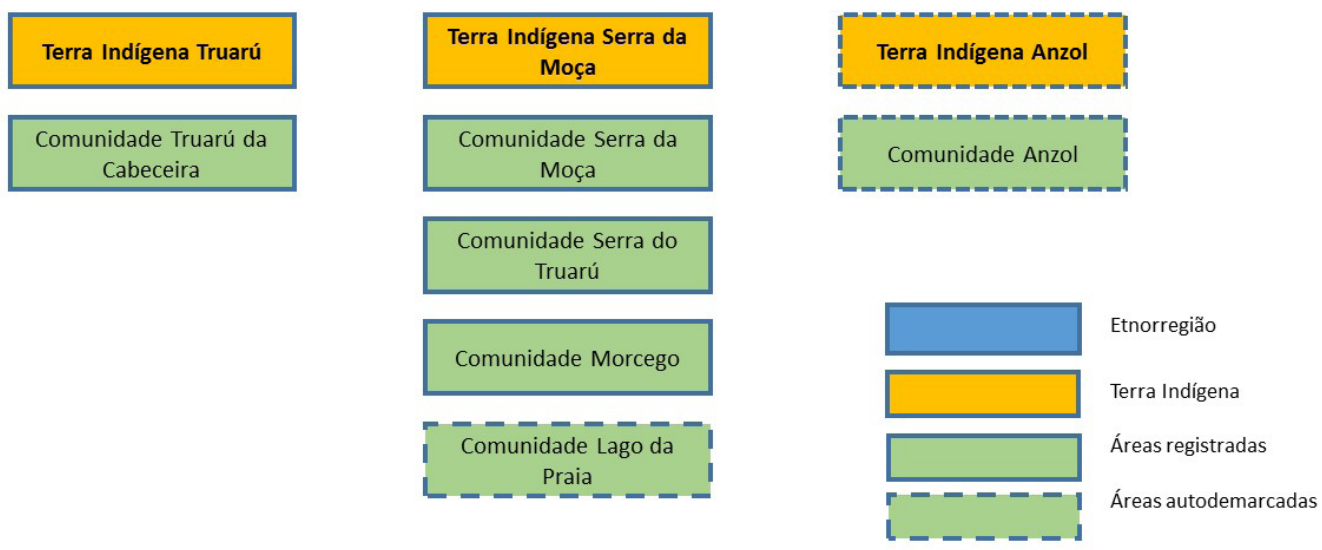

Fonte: Elaborado pelo autor, 2020.

Truarú, vem de Truaruary, que significa Cobra Grande. Dizem que essa cobra veio do rio Uraricoera por debaixo da terra e foi até um certo ponto, onde o relevo 
se tornou mais alto e a terra mais dura para escavar. Então ela voltou e permaneceu até os dias de hoje embaixo da terra, formando a serra do Truarú. Na verdade, a serra é a própria cobra. O lugar por onde ela passou acabou virando um igarapé, que também leva o seu nome. Outros dizem que essa Cobra Grande tinha sete cabeças e que cada cabeça virou um igarapé que deságua no igarapé maior. Já outros contam uma versão menos conhecida, que diz que Truarú era apenas um andarilho que vivia rodeando o "pé" da serra. Embora existam diferentes versões, o certo é que o espírito da Cobra, sempre que acordava, pegava as sombras dos mais fracos, principalmente das crianças e dos doentes que acabavam morrendo. Era necessário que os pajés fizessem rezas para ela voltar a dormir.

Ainda que eu diga que sou morador da comunidade Serra do Truarú, já faz alguns anos que saí da minha comunidade para continuar meus estudos. Em 2012, após concluir o ensino médio na Escola Estadual Indígena Adolfo Ramiro Levi, na comunidade Serra da Moça, fui cursar graduação em História na Universidade Federal de Roraima. No final do curso, em 2016, fiz da retomada do Lago da Praia a minha pesquisa para o trabalho de conclusão. No ano de 2017, ingressei em um Mestrado em Antropologia Social na Universidade Federal do Amazonas, onde aprofundei minha pesquisa sobre o mesmo caso. O contato com diferentes abordagens, bem como pessoas, tais como colegas de laboratório e professores, marcou profundamente minha formação. Por isso, mesmo que este texto não se aprofunde em discussões teóricas, é importante mencionar que ele se localiza nos estudos sobre processos de territorialização e conflitos sociais, bem como nos estudos que se debruçam sobre a ação dos povos indígenas na construção de suas territorialidades e suas autodemarcações.

Posso dizer sou parte de uma geração de indígenas que colheu os frutos de lutas históricas, com acesso à educação superior e que saiu das comunidades em busca de ferramentas que viessem a contribuir na melhoria dos nossos povos, a fim de conquistar espaços estratégicos para que novos projetos indígenas possam ser construídos. Assim, temos incluído em nossas reflexões a nossa própria vivência e agenda dos movimentos indígenas. Atualmente, estou cursando o doutorado no mesmo Programa de Pós-Graduação.

Através dessas utupa siki, "peles de imagens", como diria o Xamã Davi Kopenawa ou karichi, que quer dizer "caderno" ou "livro" na nossa língua wapichana, eu aproveito para contar um pouco da história de uma retomada de 
partes dos nossos territórios que, por diversos motivos, seja devido à usurpação de terras pelos fazendeiros, seja pela negligência dos estudos de identificação, acabaram ficando fora da demarcação.

Então, o que tenho para contar é sobre essa vivência nas mobilizações que ocorreram desde quando iniciamos os preparativos para construir o barracão que viria a ser o Centro Comunitário do Lago da Praia, passando pela ocupação das famílias que efetivamente morariam formando seus núcleos familiares, pelos tempos de quando íamos pescar e caçar livremente no rio Uraricoera e nos lagos da comunidade indígena, de quando íamos colher "murici" na beira do igarapé Muxinga e, também, do início das tensões, quando soubemos de notícias sobre os parentes que estavam sendo atacados pelos invasores, até o "fim" da comunidade, em 2009, quando a comunidade Serra do Truarú comemorava o "Dia dos Pais" no mês de agosto e os últimos indígenas tiveram que fugir do Lago da Praia porque tiveram suas casas incendiadas.

Antes de iniciar falando da comunidade Lago da Praia, é necessário retornar na história para compreendermos como o território da terra indígena Serra da Moça foi configurado a partir da interação entre os indígenas e agentes externos, tais como o Estado, como também fazendeiros e posseiros de terras, os denominados setores anti-indígenas, que historicamente foram usurpando seus territórios no atual estado de Roraima.

Essa interação a qual me refiro é evidenciada em diferentes situações históricas (OLIVEIRA FILHO, 2015), como durante o século XVII, período este marcado fortemente pelo extrativismo e aldeamentos na região do Rio Branco. Esta situação é estudada por Farage (1986), que discute a disputa territorial entre portugueses e holandeses, que utilizaram os povos indígenas da região para consolidação das fronteiras, especialmente os portugueses, através dos aldeamentos. Além disso, os aldeamentos serviam para tornar esses indígenas em servos da Coroa e, desta forma, serem incorporados à sociedade "civilizada".

Outra situação que podemos incluir como uma das que marcaram a região é a expansão da pecuária como forma de ocupação territorial. A implantação da pecuária na região do rio Branco acelerou o processo de perdas territoriais dos 
povos indígenas, como afirmam Farage e Santili (1992). Esse é um período (século XVIII e início do século XIX) marcado fortemente por esse projeto, além, é claro, pela grilagem de terras atrelada à sua regulamentação através de leis criadas a partir do advento da República em 1889.

A pecuária tinha o objetivo de manter o projeto colonial de ocupação e consolidar as fronteiras territoriais. Os primeiros rebanhos de gado bovino foram introduzidos nos campos gerais em 1787, com a criação das fazendas do Rei ou fazendas Nacionais: São Bento, São José e São Marcos; com "esse projeto, como o dos aldeamentos, também teve como objetivo consolidar as fronteiras ao norte e reafirmar de forma mais intensiva a presença portuguesa na região" (VIEIRA, 2003 , p. 35). Repetto (2008) fala na criação de diversas categorias para legitimar esta prática: fazendas, retiros de gados, missões religiosas, escolas, internatos, que, além de absorver a mão de obra indígena, contribuía para que esses povos tivesses suas terras roubadas.

A entrada do garimpo na região veio somar-se à pecuária enquanto prática desorganizada pela ótica estatal e contribuir para que os povos indígenas perdessem mais terras. Santilli (2001) afirma que esse novo fator também vem formar uma conjunção de características de interesses, por parte da incipiente sociedade regional sobre o território dos indígenas Macuxi, principalmente nos rios Cotingo, Quinô e Maú, afluentes do rio Tacutu, o que leva a um novo movimento migratório de colonos. Além dos territórios dos Macuxi, atinge também os Ingarikó, ao norte do estado de Roraima. Santilli (2001, p. 109) afirma ainda que tal prática causou um efeito devastador, contaminando rios e peixes com mercúrio e óleo diesel, além de propagar doenças como malária e leishmaniose.

Pesquisas recentes mostram que, entre as décadas de 1970 e 1990, quando ocorreram os estudos de identificação, demarcação e homologação de grande parte das terras indígenas em Roraima, esses foram marcados por graves erros, principalmente no que se refere à exclusão de partes importantes de territórios indígenas. Conforme o relatório de identificação da terra indígena Serra da Moça e confirmado na fala dos indígenas que presenciaram sua demarcação, era comumente falado que uma parte da terra seria contemplada para "garantir" e, logo após a homologação, a comunidade deveria entrar com um pedido de ampliação para que as terras indígenas consideradas insuficientes fossem revistas, conforme documento abaixo (Figura 2). Há de se levar em conta que esses estudos de 
identificação se tornavam bastante complexos devido às invasões que as áreas indígenas haviam sofrido por particulares, o que dificultava ainda mais a ampliação dos seus limites.

Figura 2 - Documento referente às revisões das terras indígenas demarcadas, 22 de julho de 1991

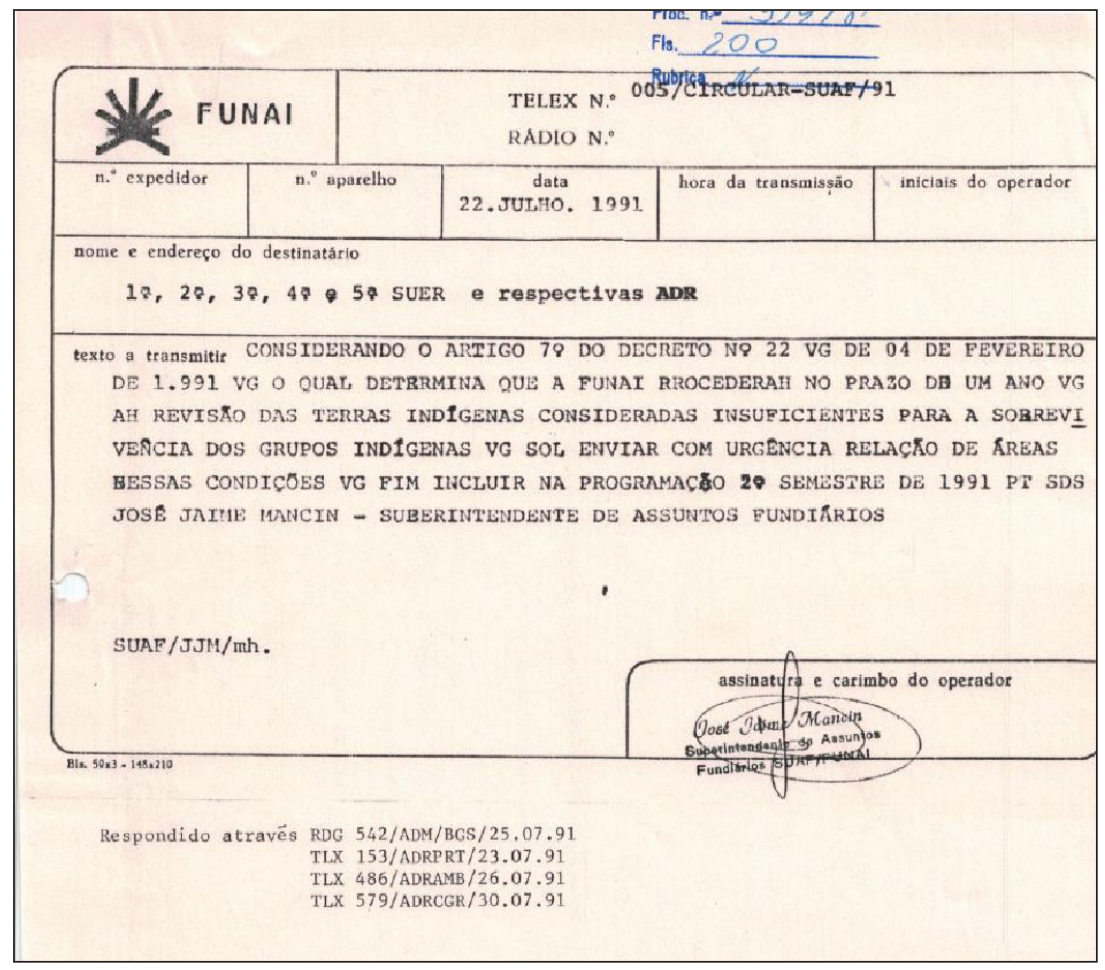

Fonte: Processo 28870.000919/1981 - 68 - Identificação da área indígena Serra da Moça.

É neste contexto que a terra indígena Serra da Moça se situa. Tais fatores desencadearam mobilizações de retomadas, tomando como elementos essas referências e experiências. Essas mobilizações são resultados de anos de uma relação violenta que os indígenas vêm sofrendo cotidianamente, seja por meio das restrições impostas, por não poderem acessar aos rios, lagos e matas, seja ainda por meio da relação de trabalhos com os fazendeiros que Ihes exploravam economicamente economicamente (ALEIXO WAPICHANA, 2020, no prelo). 
A comunidade Lago da Praia, que surgiu dessas mobilizações que reivindicavam a ampliação de seus territórios desde sua demarcação, no ano de 1991, esteve localizada ao norte da terra indígena Serra da Moça, entre o Igarapé Truarú e o Rio Uraricoera.

Figura 3 - Localização da Terra Indígena Serra da Moça como indicação da comunidade Lago da Praia em relação à Terra Indígena Raposa/Serra do Sol

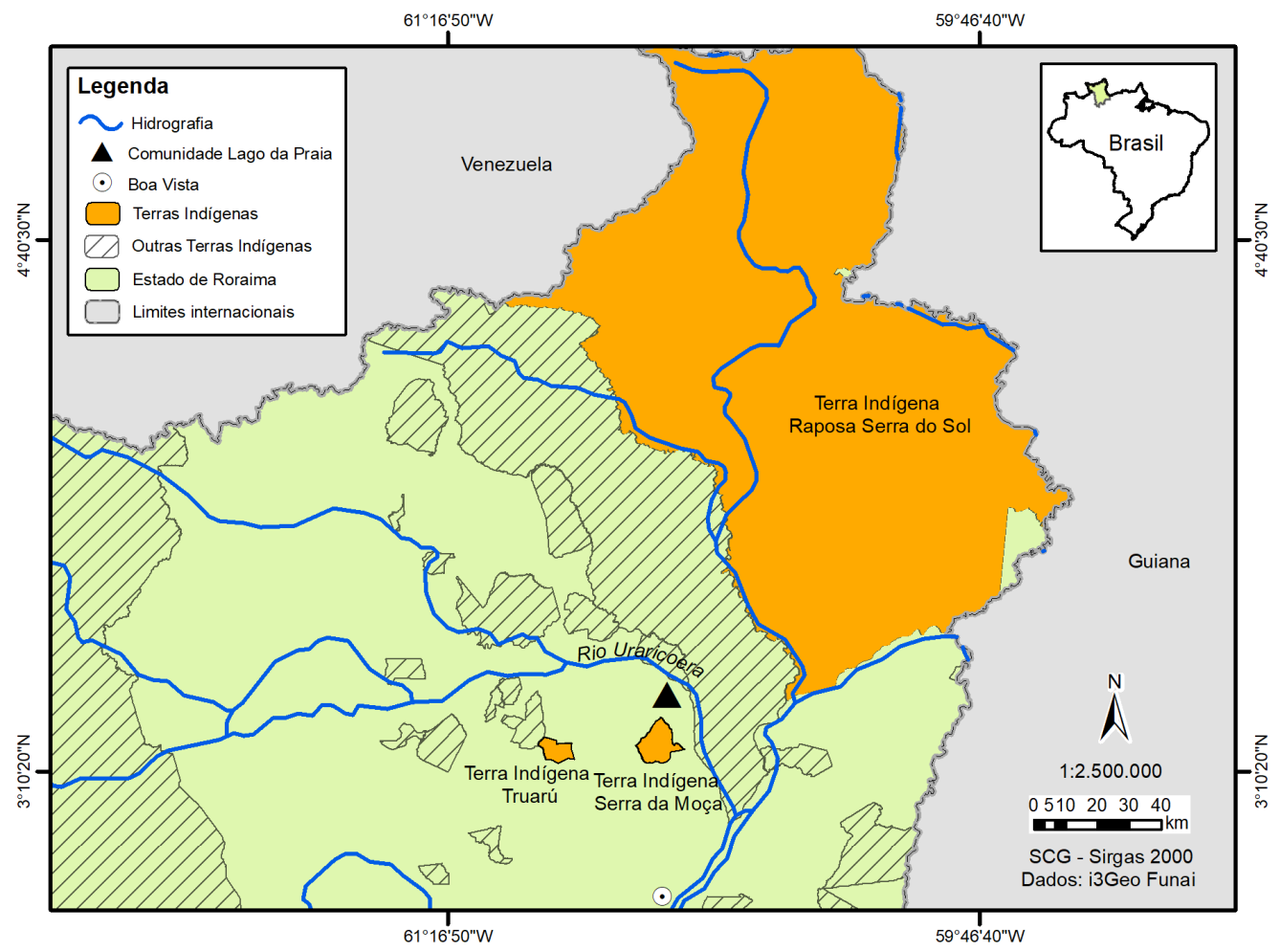

Fonte: Elaborado por Mônica Côrtez, 2020.

Contudo foi apenas no ano de 2004 que as lideranças, junto de suas comunidades, resolveram ocupar permanentemente o referido território, já que anteriormente a área funcionava como uma extensão da terra indígena utilizada para exploração de recursos naturais, tais como colheita de frutas, caça e pesca.

Sob a promessa de que a referida terra indígena seria ampliada posteriormente quando se garantisse uma pequena porção, que naquele momento 
delimitava apenas os lugares onde as famílias moravam, os Tuxauas (lideranças indígenas) não reclamaram, naquele momento, a inclusão dos territórios nos estudos de identificação.

Devido à ameaça de perda dessa extensão territorial decorrente do acirramento da luta referente à terra indígena Raposa/Serra do Sol nos anos 2000, os indígenas da terra indígena Serra da Moça resolveram então criar uma nova comunidade como forma de ocupar suas terras tradicionais, realizando, portanto, diversas mobilizações.

As negociações para a ampliação dessa terra indígena já estavam encaminhadas junto à Fundação Nacional do Índio (Funai), Conselho Indígena de Roraima (CIR), Instituto Nacional de Colonização e Reforma Agrária (Incra) e indígenas, desde o começo das tratativas. No entanto o processo foi interrompido pelo ministro do Supremo Gilmar Mendes, que fundamentou uma Ação Cautelar a favor do Governo do Estado de Roraima. O governo do estado de Roraima, no ano de 2009, era representado por José de Anchieta Junior (PSDB-RR), que entrou com uma ação no Ministério Público contra esses sujeitos envolvidos nas negociações (Funai, Incra, CIR e indígenas). O principal fundamento da Ação Cautelar referia-se à "condicionante" de número 17, que traz o seguinte texto: "É vedada a ampliação da terra indígena já demarcada" 2 .

Esse caso se tornou emblemático para o Movimento Indígena do Estado de Roraima, especialmente para o CIR, que é a organização da qual a comunidade faz parte e que acompanhou as negociações através do coordenador-geral Jaci José de Souza (Macuxi) e da assessora jurídica Joênia Batista de Carvalho (Wapichana). A posição de destaque ocorreu por ser um dos casos em que terras indígenas tiveram seu processo de ampliação ou demarcação interrompido devido a essas "condicionantes".

\section{PREPARANDO PARA OCUPAR: MÚSICA, DANÇA E TRABALHO}

A ideia de se ampliar a terra indígena Serra da Moça veio de lideranças que vivenciaram diversas experiências de luta no movimento indígena que fora

\footnotetext{
2 Tal condicionante refere-se às 19 salvaguardas impostas pelo Supremo Tribunal Federal para que ocorresse a homologação da terra indígena Raposa/Serra do Sol no ano de 2005.
} 
conjugada ainda com a opressão decorrente da relação de trabalho entre indígenas e fazendeiros.

No entanto apenas a experiência das lideranças não era suficiente para realizar a retomada das terras, era necessário também mobilizar os demais indígenas da comunidade, de forma que eles pudessem apoiar as lideranças e aderir suas ideias. As experiências internas, isto é, aquelas vividas pelo restante da comunidade cotidianamente, são também responsáveis por mobilizar e criar uma consciência crítica em relação à retomada territorial.

A combinação dessas experiências é feita em diversos momentos. Um deles são as reuniões e assembleias. E foi assim que numa reunião planejou-se toda a ocupação para a criação da comunidade Lago da Praia. Aqui recorro às palavras do tio Assis, que foi uma das lideranças que estiveram à frente da luta para descrever este momento:

Tio Assis: Tivemos reunião, que eu me lembro é assim, né: fizemos reunião pra ir pra lá e procurar as pessoas que iam, né. Aí apareceu essas pessoas e levamos carne. E lá também já estava o Banana, que era genro do Chicão, pra nos acolher lá. E de lá nós fomos trabalhar no Lago da Praia e dai estávamos lá com ele. Mas tivemos reunião pra ir pra lá. Depois que estávamos lá, começou a chegar Morcego, e daí tomaram conta já.

O que tio Assis conta é que, nas reuniões, foi planejado como seria feita essa ocupação. Acredito que foi numa semana anterior à semana que se comemoraria o dia 19 de abril, que no caso é o festejado o "Dia do Índio". Os Tuxauas decidiram utilizar essa data emblemática para não apenas ir ao lugar construir o barracão, mas também aproveitar o momento para comemorar a data com festas, comida e bebidas tradicionais.

Como é de costume, todos os anos, fazer desta data um evento em que participaria a escola da comunidade Serra do Truarú, os professores e alunos ficariam responsáveis por planejar diversas atividades de cantos, danças e brincadeiras que seriam apresentadas neste evento. E foi em uma reunião na semana anterior que foi decidido que a escola não funcionaria para as atividades regulares, mas ficaria responsável por planejar as atividades a serem apresentadas na nova comunidade.

Na semana de planejamento, duas professoras ficaram responsáveis por organizar as atividades com os alunos: Francinéia Pereira Lima e Elisangela da 
Silva Angelo. As duas eram professoras da própria comunidade Serra do Truarú e, por isso, tinham uma maior proximidade da comunidade, algo que não era tão comum com os professores que vinham de outros lugares.

Após serem delegadas para prepararem as atividades, as professoras decidiram que os alunos passariam a semana ensaiando a dança de duas músicas. Essas músicas faziam parte do repertório apresentado nas assembleias do movimento indígena e suas letras tratavam do cotidiano das comunidades indígenas, isto é, falavam de caça, de pesca, de dança, da música e da comida. Uma das músicas de que me recordo é de autoria de um compositor indígena chamado Celestino, Wapichana da comunidade Pium, Etnorregião Tabaio:

De manhã cedo pego minha darruana, arco, flecha zarabatana vou pro riacho pescar. Pegando peixe, faço a boa damurida, com pimenta malagueta, venho aqui saborear.

Na panela de barro, a damurida, no barro no balde o caxiri, peixe assado na brasa e o gosto do Assaí. É assim que vivem, os índios de norte a sul. Tem vinho de bacaba e buriti, que delícia de beiju.

Na semana de preparação dos alunos para o evento, as professoras orientaram que todos que fossem participar das atividades levassem seus trajes de dança, como saias de palhas e cocares. Muitos de nós fomos em grupos nos buritizais em busca de palha de buriti para fazer nossos trajes. Alguns até levaram para escola para fazer junto aos professores e outros alunos. Outros levaram para suas casas, onde seus pais ou avós eram quem confeccionariam os trajes dos seus filhos e netos.

Foi uma semana muito animada, porque as aulas convencionais foram suspensas e estávamos nos preparando para algo que, no pensamento dos alunos, seria grandioso; primeiro porque, como o lugar onde seria construído o barracão era distante da Serra do Truarú, muitos de nós nunca tínhamos ido até lá, apenas os homens mais velhos que conheciam porque iam caçar e pescar por aquelas bandas. Para grande parte dos nós alunos, que tinham entre 10 e 14 anos de idade, seria um lugar novo que iríamos conhecer. Tínhamos todo um imaginário de que fosse um lugar que pertencia apenas às histórias contadas pelos mais velhos, que era farto de muitas caças, como capivaras, jacarés, veados e tatus, e muitos peixes que só existiam nos lagos de lá, já que nos rios e igarapés da Serra do Truarú a presença de peixes era um tanto escassa. Parecia que lá era o lugar a ser conquistado, ao menos para as crianças, pois, para os adultos, era apenas um retorno. 
No decorrer das preparações, foi orientado pelos Tuxauas que os alunos levassem rede de dormir e corda para amarrar as redes, pois passaríamos bastante tempo por lá. Também era para levar o "kit maloca", como é chamado o conjunto de prato, colher e farinha no movimento indígena, o básico para participar de qualquer evento.

A ida dos alunos e professores estava marcada para a manhã do dia 18 de abril de 2004, pois chegaríamos ainda pela parte da manhã, passaríamos o dia todo trabalhando no barracão e, no dia seguinte, dia 19, comemoraríamos o "Dia Índio". Algumas pessoas mais velhas, isto é, pais e mães de famílias, foram antes, pois precisaria tirar os materiais necessários para construção do barracão, como madeira e palha, além, também, de capinar o local onde seria construído o barracão. Os homens foram também para preparar a alimentação para nos subsidiar durante todas as atividades e, além de matarem um gado bovino da comunidade, também aproveitariam para caçar e pescar nos locais próximos. Desta forma, não faltaria carne até o fim das atividades.

Após a semana de preparação, já no dia em que seria marcado para todos irmos, nós nos reunimos no centro comunitário, junto às professoras que ficariam responsáveis pelos alunos que iriam sem o acompanhamento de seus pais, e de lá pegaríamos o trator da comunidade e seguiríamos para onde já estavam os que tinham ido antes. Eles estariam nos aguardando com todos os materiais para a construção do barracão.

É importante ressaltar que o lugar onde se pretendia construir a nova comunidade já tinha alguns indígenas que lá moravam e que eram parentes de indígenas da comunidade Serra do Truarú, como o senhor Banana. No entanto eles não tinham nenhuma relação política com a comunidade no sentido de pertencimento, não participavam da vida comunitária indígena e levavam uma vida mais parecida com a de agricultores ou camponeses. Quando as lideranças comunicaram que ocupariam a região onde essa família morava, foram eles que recepcionaram e foi na casa deles que ficou funcionando a cozinha que forneceria alimentos para o pessoal da Serra do Truarú.

O trator que nos levaria era de um modelo muito antigo que quase não funcionava, mas tinha uma carroça com capacidade de levar alguns alunos e alunas que não tinham transporte para irem sozinhos. Outros também foram de 
motocicleta ou bicicleta nos acompanhando devagar, já que o trator não passava de $30 \mathrm{~km} / \mathrm{h}$. Cada aluno levava consigo também uma mochila enorme, onde havia mudas de roupas, redes, prato, colher, farinha e nossos trajes para apresentação no Dia do Índio.

Na manhã do dia 18, saímos do centro da comunidade rumo ao lugar que seria formado uma nova comunidade. Atravessamos o igarapé Truarú e seguimos para fora dos limites oficiais da terra indígena. Embora mais tarde chegassem indígenas da comunidade Serra da Moça e do Morcego, neste primeiro momento, participaram apenas indígenas da Serra do Truarú, que foram os que deram o pontapé inicial na mobilização.

À medida que nos distanciávamos da Serra do Truarú, a paisagem começava a mudar. Parecia ser realmente uma paisagem mais preservada, com maior densidade de buritizais e no lavrado com mais árvores, embora todos soubessem que pouco tempo atrás havia pessoas morando ali.

Por volta de duas ou três horas de viagem, chegamos à casa do Banana e, quando chegamos, já estava sendo preparado o almoço. O local onde Banana morava ficava próximo de umas das fazendas que estavam abandonadas. Na verdade, aquela região tinha diversos resquícios de fazendas, como grandes currais, casas de alvenarias e cercas. Esse primeiro local onde chegamos era conhecido como "Alagadiça", nome da antiga fazenda que havia se instalado, e foi numa casa de alvenaria que estava abandonada que nos acomodamos e deixamos nossas mochilas e nossas redes ateadas.

Após nos instalarmos, seguimos para o local onde estava acontecendo o trabalho, que era próximo de um lago. Era um lugar mais afastado de onde estava localizada a antiga fazenda. O lago que ficava próximo de onde estava sendo construído o barracão se chamava lago da Praia, isso porque ele tinha uma parte onde havia um amontoado de areia, que parecia realmente uma praia. E, mais tarde, esse lago foi utilizado para nomear a comunidade.

Quando chegamos onde estavam acontecendo as atividades de construção, já tinha muita gente trabalhando, cada pessoa executava um trabalho diferente. Os mais experientes em construções de casas montavam o sustento, como colocando as madeiras nos devidos lugares e no teto que seria coberto de palha. Os demais aproveitaram que o trator havia chegado para buscar os fechos de 
palha nos buritizais. Alguns carregam os fechos de palha na cabeça. As crianças ficam auxiliando os mais novos, como trazendo as madeiras menos pesadas para serem utilizadas. E, ainda, haviam ficado pessoas onde funcionava a cozinha para preparar o alimento, entre homens e mulheres.

O restante da manhã foi assim: entre trabalho e conversas. E nessas conversas começaram a discutir qual seria o nome da comunidade. Muitos sugeriram os nomes mais diferentes, tomando como referência os lagos e igarapés das proximidades: Lago Grande, Lago do Panelão, Lago do Porco, entre outros. Alguns sugeriram colocar o nome da comunidade como aquele lugar já era conhecido, isto é, o nome das antigas fazendas: Alagadiça e Patativa, mas as lideranças acabaram entrando num acordo de que a comunidade não deveria ter nenhum dos nomes das fazendas dos não indígenas. O mais certo seria nomear como aquela área era conhecida antes das fazendas, como Santa Rita, Caimbezal Grosso ou outro nome citado pelos antigos moradores para referenciar suas antigas moradas. No entanto acabou sendo escolhido um nome novo: Lago da Praia, porque era o lago mais próximo de onde seria o centro comunitário.

Ainda nessas discussões, começaram a ser contadas as mais diversas histórias do porquê daquele lago ser chamado de lago da Praia. Umas das versões que foram contadas, ao menos a de que me lembro, era a seguinte:

Antigamente existia uma praia muito grande, onde os pescadores ficavam sentados quando iam até o lago pescar. O lago era muito grande, escuro e farto de diversos tipos de peixe, além de muitas caças nos seus arredores, como capivaras e jacarés.

Dizem que uma vez, quando um homem estava sentado nas areias da praia, segurando sua linha de pesca, esperando pegar algo, de repente sentiu a praia se mexendo e se deslocando para lado oposto. E, quando olhou para baixo, na direção em que a praia estava indo, avistou a cabeça de um tracajá. E assim ele se deu conta de que a praia, na verdade, era o casco do tracajá coberto de areia. (Lembranças do autor).

Esta foi a história que eu me lembro de ter ouvido, embora outras tenham sido contadas, que diziam que o nome do lago era apenas por ser um amontoado de areia que as pessoas chamavam de praia e onde as pessoas se sentavam para jogar suas linhas de pesca. Não havia nada relacionado a ser um casco de tracajá nem de qualquer outro animal. Era apenas um lago com praia. 
No decorrer das atividades para construir o novo barracão da comunidade, contavam-se diversas histórias, piadas, muitos jovens aproveitavam para aprender com os mais "experientes" a construir uma casa. Outros faziam atividades que exigiam menos esforços, como levar a palha para os que estavam cobrindo o teto do barracão, que era o meu caso.

Nisso tudo, as atividades do dia 18 foram concluídas e voltamos para o local onde funcionava a cozinha, para jantar e acompanhar a reunião das lideranças, pois, no dia seguinte, no dia do evento do "Dia do Índio", estava marcado também para receberem algumas instituições que participariam e acompanhariam a ocupação, como o Incra, Ibama e a imprensa local, instituições essas que participaram de todo o processo de negociação posteriormente.

Como não conseguimos terminar de construir o barracão no dia 18, por diversos motivos, entre eles o fato de que a palha não havia secado ao ponto de serem utilizadas para cobertura do barracão, pois, se usássemos naquele dia, a palha estragaria com menos tempo, esperamos até o dia seguinte para dar procedimento às atividades. Tínhamos que acordar cedo na manhã seguinte, porque, além de ajudarmos na construção, ainda tínhamos que apresentar nossa dança e música para a comunidade.

E assim acordamos no dia seguinte e, após tomarmos café, tomamos banho e seguimos novamente para finalizar o barracão. Entre brincadeiras, histórias e piadas, terminamos de cobrir o barracão apenas ao meio-dia. E, pela parte da tarde, aconteceria a reunião com instituições.

Por isso, como não conseguimos terminar nosso barracão a tempo, os Tuxauas decidiram que os alunos não mais realizariam a apresentação de canto e dança, pois não daria mais tempo. A tia Gercina, que acompanhou esses momentos iniciais, conta como ocorreu:

Tia Gercina: Ah, foi, nós chegamos lá em 2004, nós fomos, eu não sei se foi esse mês aí de abril. Eu sei que nós fomos comemorar o Dia do Índio lá [risos]. Nós fomos comemorar lá, chegamos lá, fomos fazer o primeiro barraco, aí parece que era o Incra, né, o Incra tava lá, aí diz que nós não podíamos fazer. Só que nós não apresentamos nosso trabalho, a escola não apresentou mais. A mãe dela era aluna (apontando para sua neta de 3 ou 4 anos que estava ouvindo atentamente a entrevista com sua vó. A mãe a quem ela se refere era a Cássia, que era minha colega de turma na escola), nós fomos acompanhar também. Aí não deixaram nós fazer... 
Como não tivemos que apresentar mais, apenas voltamos para o alojamento e esperamos a parte da tarde para a reunião com as instituições. Elas chegaram por volta das 14 horas, quando todo mundo já estava debaixo do barracão, falando sobre os primeiros passos que seriam dados para a criação da comunidade.

Quando chegaram, apresentaram-se para a comunidade, falaram da situação de que aquelas terras eram devolutas e que estavam em fase de estudo para reforma agrária. E, como tia Gercina apontou acima, negaram completamente que aquelas terras deveriam ser destinadas para ampliação de terras indígenas. O Incra, na pessoa do senhor Lurenes Cruz Nascimento, havia encaminhado um ofício ao Ibama, no qual alertava sobre essa ocupação dos indígenas uma semana antes, no dia 13 de abril de 2004, e, num linguajar preconceituoso, acusou-nos de estar cometendo crimes ambientais, afirmando que os indígenas eram aculturados e conheciam as leis ambientais:

Of. INCRA/SR-25/G/RR/N. 115, de 13/04/2004

Nilva Baraúna - gerente executivo do Ibama

Comunicamos a vossa senhoria que índios da Maloca Serra da Moça estão invadindo a área da antiga Fazenda Bamerindus e matando animais silvestres como capivara, cutia e outros.

Como existe o projeto de assentamento do INCRA na referida área, solicitamos providências do IBAMA, considerando-se que os índios da Serra da Moça são aculturados e conhecem a proibição de caça e animais silvestres. $\mathrm{Na}$ oportunidade reitero a vossa senhoria voto de considerações e amizade.

Lurenes Cruz do Nascimento - Superintendente Regional do INCRA. (Dossiê Terra Indígena Serra da Moça - Lago da Praia/CIR).

Este foi um dos principais questionamentos que foi discutido pelos Tuxauas na reunião. Durante a reunião, a imprensa local também estava presente, mas os Tuxauas negaram que fosse gravada qualquer imagem, por motivos de segurança e para preservar a vida das pessoas que estavam presentes.

Por volta das 16 horas, a reunião foi encerrada, os representantes das instituições acabaram indo embora e passamos mais uma noite por lá. Na manhã seguinte, tomamos café, e quem tinha que retornar para Serra do Truarú, retornou, e quem tinha ido para morar, acabou ficando por lá na nova comunidade que tinha acabado de ser criada. E a partir daí outros indígenas das outras comunidades da terra indígena Serra da Moça começaram a chegar para construir suas moradias. 
No dia 6 de maio de 2004, o CIR encaminhou à Funai um ofício das comunidades da terra indígena Serra da Moça que havia sido enviado à Procuradoria da República de Roraima, no qual apresentam uma defesa ou esclarecimento sobre o que estava ocorrendo. Nesse ofício, inicia-se falando que decidiram ocupar a área, pois ela já estava em reinvindicação da ampliação desde anos atrás, e que a base para essa ocupação era a própria Constituição Federal, que Ihes assegurava o direito originário às terras tradicionalmente ocupadas. Ainda, informava-se que havia ocorrido uma reunião do dia 20 de outubro de 2003, na comunidade Serra da Moça, com essa pauta, e que estavam presentes representantes do CIR, Incra, Funai e Associação dos Povos Indígenas de Roraima (Apirr), aos quais as lideranças contaram as dificuldades pelas quais os povos estavam passando desde que a área foi demarcada, em 1991, além do fato de que foram deixados de fora igarapés, rios, matas.

Nesse documento, dizem também que foi garantido, numa reunião anterior à ocupação, pelo Incra (senhor Lurenes), que uma parte da antiga fazenda Bamerindus seria para as comunidades e a outra para assentar 18.000 desempregados, assim como, na semana seguinte à reunião, seria realizada uma visita para que fossem definidos os limites do que seria a comunidade.

Contam ainda na carta que o encontro nunca veio a ocorrer como combinado e, depois de esperarem muito tempo, perceberam que estava ocorrendo o assentamento e que a promessa do Incra não se cumpriria. Decidiram então, por conta própria, isto é, que não estavam sendo instigados por ninguém ou qualquer entidade, ocupar as terras que na verdade já eram deles, "pois aqui os nossos povos conviviam e usufruíam dessa terra a muito e muito anos antes mesmo de existir esses órgãos como: INCRA, FUNAI". Logo após, no documento, fazem referência à firma de JG de Araujo, dizendo que:

[...] foi nesse período que os antepassados foram expulsos, mas que deixaram para trás marcas como taperas, cemitérios e utensílios indígenas, e que isto provam que não estão invadindo e sim que estamos ocupando o que já era nosso. Apesar das pressões, ameaças e calunias que estão usando contra o nosso povo iremos permanecer no local e não vamos sair, é uma decisão nossa, lutaremos pelo que é nosso, se é pra morrer, preferimos morrer lutando pelos nossos direitos, que está assegurado na Constituição Federal. (Dossiê Terra Indígena Serra da Moça - Lago da Praia/CIR). 
Após isso, fazem referência à denúncia que o Incra fez ao Ibama e dizem que a acusação de matanças não tem provas e que já aqui é relatado que o Incra se nega a ter assumido o compromisso com as comunidades, compromisso que havia sido feito com representantes de várias instituições e que agora o Incra estava ameaçando colocá-los na Justiça para obrigá-los a sair.

Então, é relatado que no dia 17 de abril de 2007 três moradores estavam pescando quando foram surpreendidos no entardecer por alguém que eles não reconheceram, e que esta pessoa atirou numa capivara e foi embora, deixando-a baleada. É relatado ainda um conflito com um senhor que se dizia funcionário do Incra com uma família indígena que já morava há cerca de 20 anos no local, que era a família do senhor Banana, e dizem que era esse senhor não indígena que comercializava peixes e prendia tartarugas dentro de sua casa.

A carta é finalizada dizendo: "Que sejam tomadas providências cabíveis o mais rápido possível antes que aconteça algo mais grave com o nosso povo: se isto vier acontecer as autoridades responsáveis serão culpados".

\section{A CRIAÇÃO DE UMA NOVA COMUNIDADE, EFETIVAÇÃO DA MORADIA}

No primeiro momento, conforme o ofício encaminhado no dia 30 de abril de 2004 ao CIR, as lideranças informaram que, para construir uma nova comunidade, iriam 10 famílias para construir 10 casas, um barracão, 1 posto de saúde e 1 escola às margens do rio Uraricoera. E, conforme dito, foi isso que ocorreu no decorrer da construção da comunidade.

Primeiro, foram morar apenas famílias que se mudaram da Serra do Truarú, entre elas a família da tia Gercina, junto ao Tuxaua Leôncio Lourenço, seu irmão José Lourenço, Geovânia Angelo, Orlando Silva e dona Lourdes. Juntaram-se à comunidade também a família do senhor Banana, que era casado com a filha do Chicão, Anete, indígena da Serra do Truarú - e, como já mencionei, eles já moravam naquele lugar.

Conforme Geovânia, a decisão de sair de sua comunidade para ir a outra era principalmente para se ter facilidade de acessar os recursos, pois na Serra do Truarú se tinha muita dificuldade para caçar, pescar e criar, ou seja, pela oportunidade de ter uma vida melhor: 
Geovânia: É, por aqui estava fácil, está difícil; a gente vive aqui porque é nossa comunidade, nós não queremos sair daqui, eu principalmente. Aí, como tivemos oportunidade de ir aonde tinha mais espaço pra criar, pra criação, criar os filhos, nós vimos que era melhor, a terra, a água, mas não deu certo, né. Nós voltemos pra cá de novo e voltemos nossa vida normal de novo, e agora, até agora esses tempos, nós não temos mais roças; não tem nem como, assim, pra fazer farinha; não tem, a gente não plantamos mais, e é com essa seca também, ai pronto.

Quando se iniciou a comunidade, foram chegando outras famílias das outras comunidades, Morcego e Serra da Moça, e, conforme foi chegando, a efetivação de suas moradias aconteceram em concordância com toda a comunidade, obedecendo aos critérios específicos de suas territorialidades, ou seja, os indígenas dessa comunidade passaram a escolher os lugares para construírem suas casas em ambientes que eles consideravam bons, estratégicos para morar, criar, plantar e se locomover.

Por exemplo, a fala da Geovânia demonstra como ocorreram essas escolhas dos lugares, tendo como principal critério de seleção do lugar a proximidade do igarapé Truarú, em um lugar onde se localizava uma antiga fazenda chamada Patativa:

Geovânia: Então, nós escolhemos o lugar, próximo, quase próximo do Truarú. Nós fomos, moremos, a gente morava longe do "Centro". O centro era ali na Alagadissa, o centro que a gente fizemos a reunião, e aí a nós escolhemos o lugar [que] seria bom. Se fosse lá onde o seu Banana morava ou era aqui no Alagadissa. Como ficou distante de onde ficava da nossa casa que era fazenda a mesma distância da fazenda do Banana, a gente fiquemos lá no Alagadissa. O centro, concordemos que o centro seria lá, que aí o pessoal chegava no mesmo horário, de lá como daqui.

Observemos também que o lugar deve ser estratégico, tanto por ser próximo de uma fonte de água, como também um lugar considerado bom para criação de animais, como galinha e suas plantações, e por isso a distância do centro comunitário é levada em consideração, porque assim suas criações não iriam até o centro fazer sujeiras.

Já tia Gercina conta que a escolha do lugar onde construiu sua moradia foi também por estar próximo da rede de água, onde seria mais fácil cavar um poço. Além disso, era porque o lugar não apresentava tantas elevações, era "plainado", ou seja, era mais fácil para locomoção das pessoas: 


\section{Eriki: E o lugar onde vocês fizeram a casa, porque vocês escolheram aquele lugar?}

Tia Gercina: Aquele lugar lá porque lá era rede de água. Naquele local onde nós chegamos, a água era bem baixa, o poço que saiu ficou bem rasinho. Porque para lá era mais alto. Não, nós vamos fazer, nós vamos fazer, isso aqui só para nós começar, mas nós não vamos morar aqui não, nós vamos morar mais pra lá assim, que tem um lugar assim bem plainado lá [...].

Dona Lenice, que era esposa do finado Jairo, que na época era uma liderança, tinha sua casa construída próximo ao centro comunitário, onde também seu sogro e sua sogra já haviam escolhido para morar.

\section{Eriki: E o lugar que vocês escolheram pra morar lá, como que foi...?}

Dona Lenice: Não sei, porque o lugar que a gente escolheu, a dona Carminha já tinha essa casa. Aí, como nós ficamos nessa casa dela que ela escolheu lá para o outro lugar já que era casa dela, foi lá perto dessa fazenda. Porque só lá que tinha um poço, mas aí, depois, cavamos o poço da escola, nós carregava água de lá, depois que a gente pagou o menino pra cavar um poço lá pra nós. Água, dava água boa também lá. Que eu me lembro.

A proximidade do centro comunitário também é pensada por ser estratégica para se construir a casa de uma Liderança, pois assim ficaria mais fácil para Tuxaua ser encontrado para os problemas que pudessem vir a ocorrer na comunidade. Sua casa acaba se tornando um ponto de referência para as instituições de fora. Podemos identificar também que neste local, em específico na casa da dona Lenice, moravam duas lideranças, seu sogro, Jaime, que era Tuxaua do Lago da Praia, e seu esposo. Além disto, pode-se pensar que, como o lugar escolhido para construção da casa era onde sua sogra morava, a dona Carminha, percebe-se que ali estava se concentrando um núcleo familiar.

O centro comunitário foi criado com base nas comunidades das quais as famílias vinham: além das casas das famílias, uma comunidade tem que ter alguns elementos essenciais: uma escola, para suprir a necessidade dos filhos, um posto de saúde e uma casa de fazenda.

Desta forma, o centro comunitário acabou mudando de lugar, já que no início o barracão que foi construído em 2004, próximo ao Lago da Praia, acabou ficando de fora no decorrer das negociações com o Incra, o que falarei mais adiante. 
Por isso, foi escolhido um outro lugar para ser construído o centro comunitário, que era próximo de outra antiga fazenda e próximo ao rio Uraricoera. E, no decorrer do processo de consolidação da comunidade, foram construídos a escola e o posto de saúde e, consequentemente, esses tornaram-se pontos de referências para a comunidade, que os utiliza para construções futuras, como campo de futebol, espaços para os eventos comemorativos, igrejas etc.

Se o nome da comunidade foi escolhido no momento da ocupação e um dos critérios para a escolha era que fosse um nome de algum lugar com referências indígenas, o mesmo não ocorreu com a divisão territorial da comunidade, ou seja, os lugares de referências onde as famílias vieram a morar passaram a ser identificados pelos nomes das antigas fazendas. Assim como na Serra do Truarú, em que determinados núcleos familiares criaram suas territorialidades a partir de uma divisão territorial interna, o mesmo ocorreu no Lago da Praia, como falado pela Geovânia:

\section{Eriki: Por que ficou dividido com esses nomes?}

Geovânia: Porque esses nomes, esses lugares é onde tinha fazenda; era o nome dos antigos fazendeiros. Ficou tipo bairro, assim. Ficou lá Alagadissa, que era uma fazenda lá também; ai lá no Patativa era outra família, tinha outra família que era seu Orlando.

A comunidade ressignificou os nomes das fazendas, uma vez que, no início da comunidade, havia ocorrido uma resistência das lideranças para que não se utilizassem os nomes dos "brancos", e agora os nomes das antigas fazendas, Patativa, Alagadiça, foram incorporados na dinâmica da divisão territorial, tornando-se referências para as famílias do Lago da Praia. Esses resquícios das antigas fazendas, como as casas de alvenarias, os currais e toda uma estrutura completa de uma fazenda de gado bovino, fora também utilizada para criação da fazenda comunitária. Gecivaldo, esposo da Geovânia, foi um dos vaqueiros comunitários, e por isso eles foram morar em uma dessas antigas fazendas para tomar conta do gado comunitário.

De 2004 até 2009, a comunidade desenvolveu-se em um ritmo acelerado, tanto que se tornou, em termos de comunidade indígena, uma das maiores produtoras de gado bovino do estado de Roraima, chegando a ter 597 cabeças de gado. Geovânia e tia Gercina contam como viam esse aumento do gado. 
Tia Gercina: Pois é, essa ideia que teve partiu pra lá, que tem mais terra pra gado, né, também, também pra criar gado. E foi muito bom né, os gados.

Eriki: E vocês levaram os gados?

Tia Gercina: Levamos o gado da comunidade, e aumentou nesses cinco anos, nesses cinco anos aumentou mesmo, bastante, tava chegando uns 600 "reis" [...].

Como Geovânia tinha sido uma das pessoas que tomou conta do gado junto ao seu marido Gercivaldo, pôde acompanhar de perto esse crescimento. O gado havia sido levado da Serra do Truarú e Serra da Moça para o Lago da Praia. Esses gados pertenciam ao projeto "Uma vaca para o índio", que era um projeto implantado pela Igreja Católica nas comunidades indígenas na década de 1980. O projeto tinha como objetivo fazer com que as comunidades criassem esses rebanhos bovinos coletivamente. Foi um projeto importante para assegurar os direitos territoriais dos povos indígenas de Roraima. De acordo com a antropóloga e membro do Conselho Indigenista Missionário (Cimi) Gilmara Fernandes Ribeiro (2018, p. 94):

O projeto Uma vaca para o índio, favoreceu uma melhor qualificação, formação e capacitação dos indígenas para lidarem com seu próprio rebanho. Assim os indígenas têm autonomia para criar seus rebanhos. Com isso também, concebem o gado, deixando de ser uma prática do branco, para uma nova identificação, índios criadores o que lhes possibilitou desenvolver uma forma de criação buscando sua autonomia e principalmente, para que pudessem negar todas as formas de opressão que viveram no passado através das fazendas.

E não foi diferente da comunidade Lago da Praia. O rebanho aumentou de forma acelerada, tanto que era para o gado passar apenas dois anos sob o cuidado do vaqueiro do Lago da Praia, mas, como estava aumentando, ficou por mais anos, até quando tiveram que sair de lá.

Geovânia: Aí passado alguns tempos, aí escolheram Gecivaldo como vaqueiro. Ele passou dois anos cuidando dos gados da comunidade. Aí eles trouxeram de lá, porque eles estavam entrando lá pro assentamento, os gados estão no Banana. Colocaram pra perto do rio que lá tinha mais capim pra eles. Capim, água, bastante água. Então a comunidade se reuniu de novo e colocaram. 


\section{Eriki: e aumentou muito mesmo.}

Geovânia: aumentou, bastante, porque na verdade eram cinquenta "reis", né, por comunidade. Eu acho que são cinquenta "reis". Eu sei que aumentou bastante. Aumento bastante mesmo, chegando a quase duzentos.

\section{Eriki: E essas "reis" vieram de onde?}

Geovânia: Do projeto que eles dão "uma vaca pro índio", não tem? Pois é. Esse projeto é que era daqui da Serra da Moça, pra Serra da Moça passar pra lá. Aí era pra passar só um ano. Como estava produzindo bastante, deixaram passar mais dois anos, porque tava muita produção, e se eles ficassem um ano, a gente já ficaria com a metade dos gados, porque nasceu muito mesmo. Porque lá tinha os capins, os capins são bons e eles são daqueles pra gado mesmo, "ticuia". Eu não me lembro bem o nome; na beira do rio, tinha só esse capim, não tinha um capim "nativo" assim não.

Além do aumento do rebanho bovino, a agricultura também foi uma das principais atividades que prosperam entre as famílias do Lago da Praia. Produziram diversos tipos de frutas, mangueira, maracujá. Tudo que eles plantavam ou faziam dava certo, como criação de galinha e porco.

Geovânia: [...] E dava muito leite, muito leite das vacas, cavalos também, aumentaram também; assim a produção desses animais assim era bom; galinha também, "meu", você tinha que ver.... eu criei quase cento e pouca cabeça de galinha lá. Muitas galinhas eu criei; porque a terra, eu acho que a terra é boa pra tudo assim; pra plantação, pra melancia, pra qualquer coisa. Nós plantávamos melancia, é... melão, maxixe, mandioca, macaxeira, nós plantemos banana. Lá no sítio nós plantemos caju, maracujá. Maracujá deu que só lá; Maracujá. Não sei se tu se lembras.

Dona Carminha, uma senhora Macuxi da comunidade Morcego, esposa do Tuxaua Jaime e mãe do Tuxaua Jairo, foi umas das moradoras do Lago da Praia. Ela conta como era sua vida no Lago da Praia, cheia de fartura, diferente de como era depois que ela tinha voltado para comunidade Morcego:

Dona Carminha: Ainda hoje eu estava falando que o menino disse ali, o filho do Ricardo: "Papai, quando nós morávamos no Lago da Praia, sobrava dinheiro, por quê?" Ninguém comprava peixe, ninguém não comprava capivara, ninguém compra o tatu, a gente matava, comia, pescava, comia. Lá tinha dinheiro, agora aqui: a gente compra galeto, a gente compra o chambaril, não sobra nada, ele disse, sabe por quê? Porque a gente pescava. A gente não comprava mesmo, mas aqui a gente não tem onde pescar, aqui é tudo 
cercado aí, pra gente pescar lá no rio, tem que pedir, aí, se não pedi eles dizem que a gente tá roubando.

Durante este tempo no Lago da Praia, a comunidade prosperou bastante, como narra Geovânia, falando de como todos viveram e como todos eram participativos na construção de algo que viria a beneficiar a todos, como escola, posto de saúde: "era uma coisa assim, parece que era um sonho [risos]".

E conforme a comunidade foi crescendo, foi construída uma escola que funcionava como uma sala anexa à escola da comunidade Serra da Moça, já que o governo não poderia criar uma escola por decreto devido à comunidade não ter números de alunos suficiente e pelo fato de a terra ainda não ser homologada. Então, os professores que trabalhavam no Lago da Praia eram contratados pela escola da Serra da Moça. A comunidade do Lago da Praia se reuniu para construir um barracão de palha que funcionaria como uma escola.

Geovânia: Nós fomos, ajudemos na escola também. Todo mundo ajudou a "bater" tijolos para levantar. Nós carregávamos, as mulheres e as crianças carregavam tijolos para a escola. Lá para o posto de saúde eu não ajudei muito mais, porque eu estava quase saindo. Eu não ajudei a construir. $O$ posto de saúde não. Mas a escola assim e casa de apoio eu ajudei a fazer. A gente fez um poço. Os homens caíam dentro e as mulheres puxavam assim. Os homens só para cavar e as mulheres só para puxar barro. As mulheres que não tão na cozinha estavam trabalhando. Mas maioria que cozinhava era dona Lenice e dona Carminha e tia Gercina. Elas sempre ficavam na cozinha. Agora os mais novos sempre estavam no trabalho mesmo, trabaIhavam assim.

Chegaram também a construir um posto de saúde e uma casa de apoio para abrigar os professores que iam trabalhar na escola da comunidade. E, com muito trabalho coletivo, lutas diárias e muita alegria por estarem voltando às suas terras, a comunidade foi sendo construída.

Tia Gercina: três anos assim tranquilo, como a gente ia morar mesmo nós formamos a escola. A gente já tinha formado a escola feita de palha, de barro, parede de barro, com tudo dentro. Eles começaram, dentre três anos nós vivemos bem. A gente estava pensando em nunca sair de lá porque vivíamos muito bem. Lá tinha muito peixe por causa do lago e do rio. Não era que nem aqui. De vez em quando mata uma "reis". Mas era difícil a gente matar por causa da caça, do peixe, a gente pegava só para comer também. 
A gente não caça ou pescava para vender; lá tinha tudo: tinha, jabuti esse aí a gente nem comia porque eu nunca gostei de comer jabuti, mas tinha jabuti demais; jacaré também eu nunca gostei de comer, mas tinha bastante. Quando nós vivemos lá o pessoal da prefeitura levaram o "meio ambiente" e incentivou para a gente não acabar com as coisas, a natureza, com as matas, então a gente nunca mexia, nunca mexia nada. Estava tão bem. Ninguém danificou nada.

\section{CONVIVÊNCIA COM OS ASSENTADOS}

Embora saibamos que, historicamente, a relação entre indígenas e não indígenas é marcada por relações assimétricas, nas quais os primeiros sempre foram alvo da violência física e simbólica, pode-se dizer que, no início da comunidade Lago da Praia, existiu uma relação de certa forma pacífica com os assentados ${ }^{3}$ que foram retirados da terra indígena Raposa/Serra do Sol. Como eles chegaram no ano de 2005, logo após a Raposa/Serra do Sol ser homologada, Lago da Praia já tinha um ano de existência. Por isso, quando os assentados chegaram, foram buscar ajuda dos indígenas para se estabelecerem, construírem suas casas; quando precisavam de água, iam tirar nos poços da comunidade. E isso nunca foi negado pelos indígenas.

Antes de os assentados chegarem para ocupar parte da terra que estava sendo reivindicada para ampliação, ocorreu uma reunião no dia 18 de agosto de 2004, na qual estiveram presentes representantes da Funai, Incra, Ibama, CIR, Associação dos Assentados e trabalhadores rurais de Roraima. Esta reunião tinha como objetivo de acordo o ofício encaminhado ao então presidente do Incra, Dr. Holf Hackbart, pelas lideranças do Lago da Praia, que dizia o seguinte:

[...] objetivo desta reunião foi para fechar o acordo entre os indígenas e produtores rurais na delimitação das terras prometidas pelo superintendente do INCRA aos povos indígena da Comunidade Serra da Moça, Serra do Truarú e Morcego. Depois de várias propostas, foi fechado o acordo na presença de todos os participantes da seguinte forma: 10 ponto seria na boca do Igarapé muxinga com Igarapé Truarú, acompanhando o limite natural até o 2 o ponto; depois, cortaria em uma linha seca até Cabeceira do Igarapé

3 Utilizarei esta categoria para me referir aos ocupantes por parte do Incra. Esta categoria aparece sendo utilizada pelos indígenas em seus documentos, inserida em contexto de disputas e ameaças, mas também vai aparecer em outros documentos da associação dos próprios assentados para se autorreferirem. 
Carraspano, deixando três lagos para os assentados e três lagos para os povos indígenas; do 3 o ponto, acompanharia novamente o limite natural até o 4 은 ponto e, novamente, cortaria em linha seca, deixando fora a margem do rio Uraricoera desmatada para o plantio, até o ponto do Igarapé Truarú, e acompanharia o Igarapé até o 1 ㅇp ponto, fechando assim o limite. Foi também concordado que os assentados utilizariam a estrada que dá acesso à área de plantio à margem do rio, enquanto a outra estrada fosse recuperada. Todo o trabalho foi feito conforme o acordo. Informamos também que esse acordo entre os assentados e lideranças indígenas foi feito pacificamente em ambas as partes para no futuro não haver desentendimento entre os povos indígenas e os produtores.

Como podemos ver, indígenas e assentados viveriam dividindo as fronteiras territoriais. Devido à proximidade, ao longo do tempo, passaram também a conviver cotidianamente, porque os assentados começaram a adentrar a comunidade; nos fins de semana, iam às praias dos rios que estavam localizadas dentro da comunidade, além de frequentarem a escola indígena.

Dona Carminha conta como era a relação com um dos assentados, chamado Fábio, na qual este indivíduo frequentava cotidianamente sua casa:

Dona Carminha: Esse Fábio aprendeu fazer damorida comigo para ele comer, comia junto com a gente e ainda foi fazer essa coisa para nós. Por isso que diz, ser amigo, depois mais tarde, vem, ficava com raiva. Ficou com raiva de nós. Ninguém ficou com raiva de ninguém, mas eles que ficaram assim, botaram na cabeça deles, né. Era para plantar arroz ali, mas até hoje, nunca nem vi se plantaram arroz.

Esta fala nos revela duas coisas: a primeira é que, da parte dos indígenas, eles sempre estiveram disponíveis para ajudar os assentados, uma vez que, nas reuniões anteriores, ficou acordado que cada um ficaria com uma parte da terra, tanto indígenas quanto assentados teriam um lugar para morar, portanto, não havia motivos para iniciarem uma briga posteriormente. No entanto dona Carminha descreve que, "depois mais tarde", isto, já em 2008, iniciou-se uma discordância, motivada por influências de empresários plantadores de arroz. Os empresários que são citados eram os que já estavam envolvidos no conflito da terra indígena Raposa/Serra do Sol e que, quando houve a homologação, passaram a influenciar os assentados para que iniciassem uma briga com os indígenas do Lago da Praia, de forma que eles também pudessem tomar suas terras. 
Uma das formas que se mantinha essas relações, entre indígenas e assentados, era através dos eventos promovidos pela escola, já que os assentados não tinham uma escola rural, e, como só existia a escola do Lago da Praia, os filhos dos indígenas e dos assentados estudavam juntos. E, através disso, eles participavam dos eventos e até da vida política da comunidade:

Dona Carminha: Nós pescávamos, quando eu fazia, eu me lembro das "pongós" que eu puxava no igarapezinho, no lago, perto do seu Leôncio. Nós pegávamos era muito, com caniço. Agora aqui ninguém vê pongó.

Seu Jaime: Aqui não tem nem água, "vali" peixe.

Dona Carminha: E é tudo longe aqui. Lá era tão perto. A gente ia lá rapidinho, você pegava o almoço, fazia pesqueiro né, aí pegava.

\section{Eriki: Vocês faziam muita festa lá, caxiri, damurida?}

Dona Carminha: Eu achei engraçado, foi bonito, que eu me lembro, foi nos "Dias dos Índios" que nós fizemos. Foi Gercivaldo que matou um veado. Nesse dia fizemos só damorida e foi só veado mesmo, peixe era com o pessoal que vieram, do assentamento.

\section{Eriki: Vocês convidavam ainda?}

Dona Carminha: Convidavam, ora se eu tô dizendo, vinham, comiam, comiam junto com a gente, ninguém ficava encrencando, quando eles passavam, aí, a gente convidavam. Inventaram essas festinhas de festa junina, aí brincavam, depois se zangaram, era porque queriam tomar mesmo. Pensavam que 0 Incra ia deixar eles plantar, mas não plantaram.

Como os filhos dos assentados também estudavam na escola do Lago da Praia, os pais também participavam dos eventos promovidos na comunidade. Eles iam partilhar das comidas e bebidas que eram levadas pelos pais dos alunos, além de participar de todas as atividades esportivas, festas e danças.

\section{NEGOCIAÇÃO: DIMINUIÇÃO DA COMUNIDADE LAGO DA PRAIA}

A princípio, a área que estava sendo pleiteada pelos indígenas da Serra da Moça era de uma extensão de 11 mil hectares, a qual correspondia a uma extensão contínua da terra indígena. Todos os lagos e igarapés estavam incluídos nessa nova extensão da terra. Essa configuração territorial era algo que vinha sendo discutido no movimento indígena motivado pela disputa da terra indígena Raposa/Serra 
do Sol, no qual se lutava para demarcar as terras indígenas em áreas contínuas, em vez de áreas em ilhas. Por isso, a extensão da terra reivindicada era junto à terra indígena já existente.

No entanto, após a reunião do dia 18 de agosto de 2004, conforme ofício apresentado anteriormente, houve um acordo em que os indígenas abririam mão de parte da terra para que fosse destinada à reforma agrária e aos "desintrusados da Raposa/Serra do Sol". Desta forma, foram divididos os recursos naturais, como lagos, igarapés, matas e buritizais. A extensão da terra pleiteada foi reduzida para bem menos do que era reivindicado. No croqui elaborado pelos indígenas, a área em vermelho indica o que estava sendo pleiteado após as negociações, correspondendo agora a apenas 7 mil hectares. A área em verde corresponde à área já demarcada.

Figura 4 - croqui elaborado para identificar a área da comunidade Lago da Praia

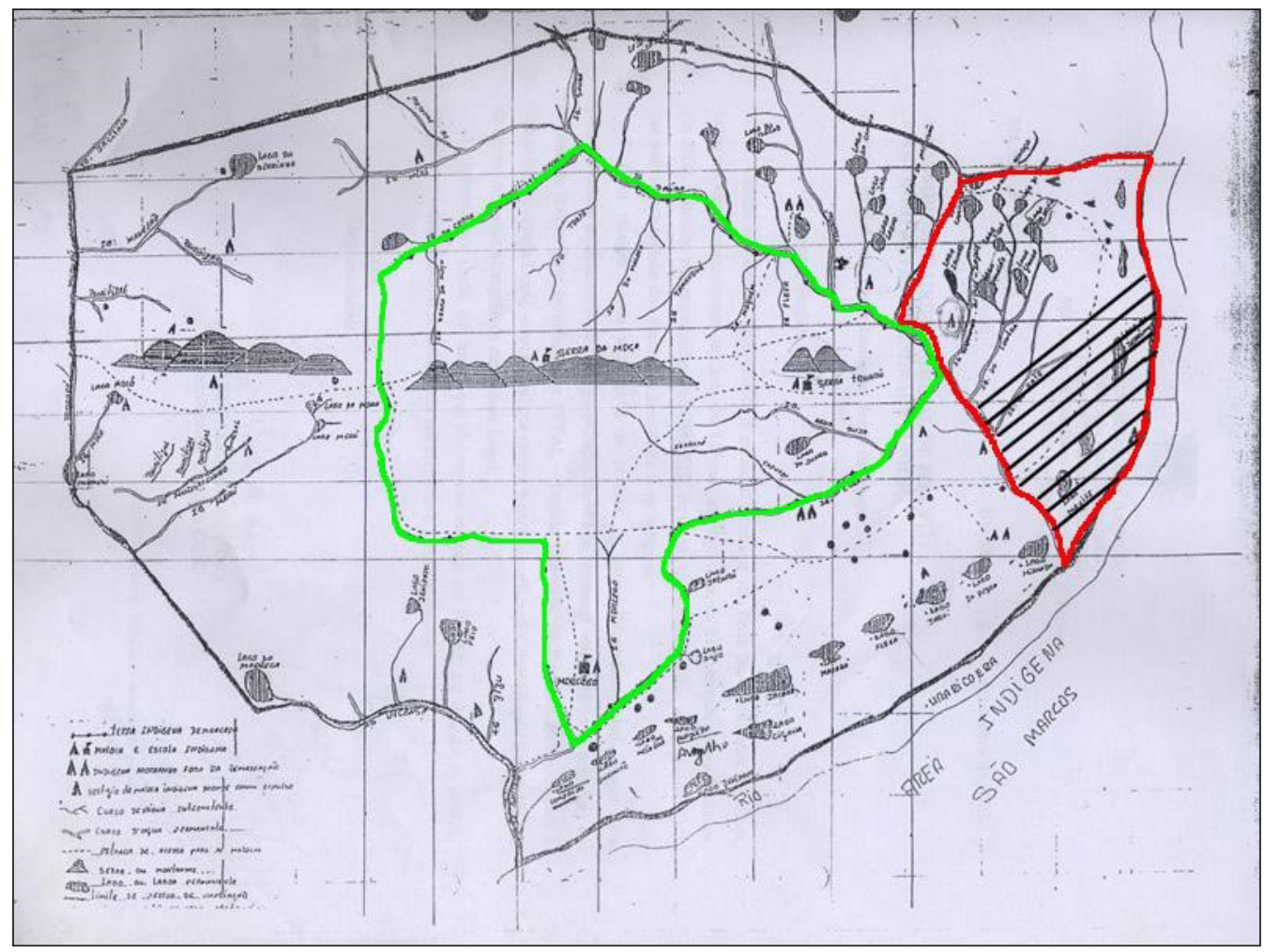

Fonte: Dossiê Terra Indígena Serra da Moça - Lago da Praia/CIR, modificado pelo autor. 
O croqui a seguir, elaborado já conforme as negociações, corresponde à área em hachura do croqui anterior.

Figura 5 - croqui de mapa identificando a comunidade Lago da Praia após negociações com assentados

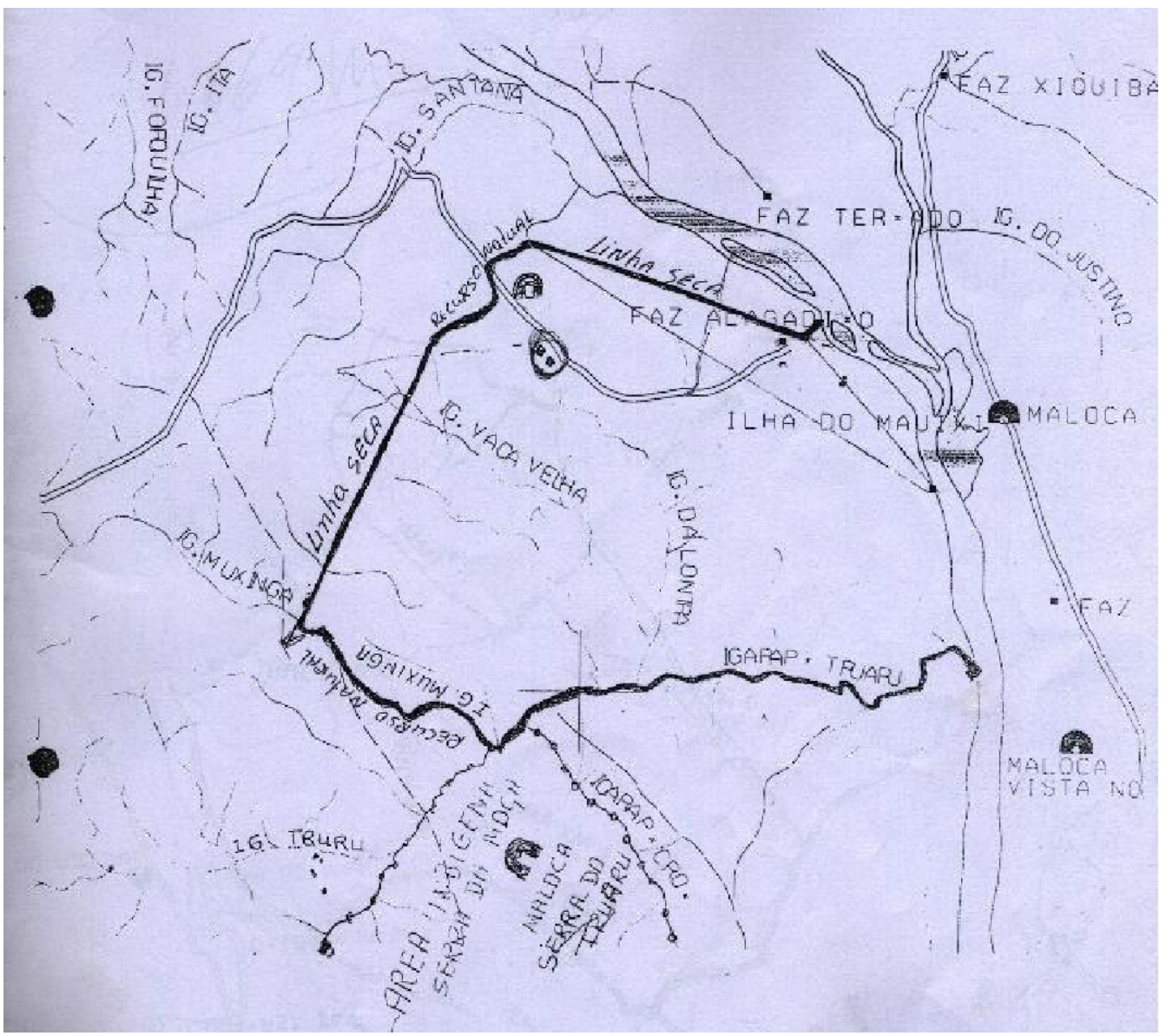

Fonte: Dossiê Terra Indígena Serra da Moça- Lago da Praia/CIR, modificado pelo autor.

Mais uma vez, recorro à fala da tia Gercina, que conta como ocorreram as negociações, quando, na época, seu esposo Leôncio era Tuxaua.

Tia Gercina: Quando o Leôncio, nós estávamos esperando essa terra, mas ela era de 11 mil hectares, aí eles diminuíram pra 7. No final, já pra nós, quando foi para decidir pra de sair, ela era só com 3.3 mil hectares apenas. 
Já não sei nem onde era. Talvez bem perto da beira do rio. Só com 3 hectares quando nós saímos; diminuíram. O governador decidiu dar "eliminar [liminar]" pra nós, pra nossa escola não ser reconhecida mais, aí pronto, foi quando acabou, não podia porque a terra não era regularizada.

Não tive acesso ao mapa que indica quando a comunidade se desfez, no entanto, de acordo com o relato acima, a terra que, a princípio, era de $11 \mathrm{mil}$ hectares, após o acordo com os assentados passou a ser de 7 mil (Figura 4 e Figura 5). Após o início do conflito, as famílias indígenas que moravam mais afastadas do centro comunitário mudaram-se mais para perto, deixando, assim, mais áreas desocupadas. A terra passou a ser apenas de 3 mil hectares e era assim que a terra estava quando a comunidade foi desfeita. Neste processo de negociação, até o lago da Praia que tinha dado nome para a comunidade acabou ficando de fora.

Antes de a comunidade se desfazer, o Incra tentou solucionar o conflito entre indígenas e assentados. O senhor Lurenes, superintendente regional do Incra Roraima, durante as negociações, fez a seguinte proposta ao Tuxaua Jaime: já que o conflito estava perdurando por muito tempo e se agravando cada vez mais e sem nenhuma previsão de haver demarcação, a terra seria dividida entre as famílias indígenas como se fossem loteamentos. Cada família teria um lote individual e, assim, resolveria a situação com maior agilidade, evitando-se conflitos entre indígenas e assentados. No entanto esta proposta foi negada pelo Tuxaua, dizendo que esse modelo de divisão territorial adotado pelo governo não correspondia à organização social indígena:

Tuxaua Jaime: Aí disse que ia fazer loteamento para nós, assim: "Olha Tuxaua nós estamos querendo fazer um acordo, fazer loteamento, como área indígena, mas fazendo cada um ter o seu lote, porque não vai ter muito problema; você pega o seu lote, aí já é seu, outro também pega". Então eu falei para ele: olha, digo: "Não! Eu não aceito dessa maneira porque não vai dar certo". "Por que que não vai dar certo? Por que o senhor diz isso, Tuxaua, que não vai dar certo?"; "Não vai dar certo porque eu sei que não vai dar certo, porque eu estou vendo o pessoal do assentamento que o senhor assentara: hoje tem casa que é terreno abandonado e outros acabaram vendendo, porque não pode, né". Não pode vender e estão vendendo, só pega o lugar, depois vende para outro. E nós indígenas não somos assim. Nós, como indígenas, nós moramos num lugar, a gente mora um perto do outro, mas aí ninguém empata ninguém fazer roça, ninguém empata ninguém de tirar palha, ninguém empata ninguém de tirar madeira, ninguém empata o pescar, nem 
caçar, do jeito que o senhor quer fazer para nós. Não vai dar certo, porque o parente vai pegar uma parte da mata, vamos dizer assim, vai pegar e aquela área é dele, e o outro pega a parte do lago, o outro pega a parte do buritizal, e aí? Quando, se for demarcado, se demarcar cada um com seu lote, não vai dar certo porque o parente mesmo vai procurar confusão; ele vai dizer: "não esse aqui é meu, esse aqui eu ganhei e ninguém pode tirar não"; só se ele autorizar a gente pode tirar, se não, ninguém pode. Mesmo coisa no lugar de mato, se ele for entrar para trabalhar: "não, esse aqui é meu, você não pode botar a roça. Esse lago aí está no meu terreno, ninguém pode pescar não". Então é assim, então, o que a gente está querendo, eu falei para ele, é um lugar, um terreno pra todo mundo tá junto, trabalhando junto, caçando junto, pescando. Aonde tem seu buritizal, todo mundo tira, faz seu barraco, que onde vai caçar, pesca, pega o peixe, caça, tudo aí, ele não vai ter problema nenhum, e se dividir assim como você está pensando não vai dar certo. Ai ele pensou e disse assim: "Não, Tuxaua, o senhor tá certo, mas a gente estava querendo fazer isso pra ver se acabasse essa confusão pra não ter mais. Ai levava lá no Incra, a gente fazia toda papelada, vinha, né, mas não, eu digo não, se quiser fazer, deixa livre, do jeito que tá, não precisa fazer do jeito que o senhor tá dizendo, porque depois tem parente que não vai, ele não vai aceitar isso aí, né, tem parente que entende, ele vai entender, mas tem parente que não vai entender desse jeito [...].

Ao fim, não se fizeram eficazes as negociações envolvendo indígenas, assentados, Funai, Incra e organizações representativas desses sujeitos envolvidos. Os acordos de divisão territoriais acabaram não sendo respeitados por parte do Incra, resultando em um conflito iniciado em 2008, no qual foi marcado por violência física e simbólica, ameaças e casas queimadas, como veremos a seguir.

\section{O CONFLITO}

Conforme demostrado nos documentos e nas falas aqui apresentadas, a negociação apontada anteriormente já resolvia a disputa territorial entre indígenas e assentados, na qual 7 mil hectares estavam destinados à ampliação da terra indígena Serra da Moça, enquanto outra parte seria para o Incra proceder com a elaboração de projeto destinado aos assentados, denominado Projeto Nova Amazônia - Truarú.

No entanto, neste meio tempo, como já foi narrado, iniciou-se um conflito no qual os assentados passaram a ameaçar os indígenas do Lago da Praia, queimando suas casas, suas plantações, roças, o posto de saúde e a escola da comunidade, que os assentados também utilizavam. 
Seu Jaime: Nós moramos cinco anos lá dentro. E saímos rapidinho assim. Quando fez cinco anos que a gente chegou, começaram a invadir e começaram a botar para a gente sair. Não foi porque a gente queria sair de lá, foi por causa deles, que botaram, que faziam a bagunça deles. De noite ou de dia, ficavam correndo para lá e pra cá, tudo armado de terçado. A gente não podia fazer nada, não íamos brigar com eles, até que começaram a queimar casa. Começou primeiro pelo colégio, depois queimaram o posto, onde a Luzia trabalhava, era Luzia que era enfermeira. Queimaram. Tinha rádio fonia que tinham colocado para, queimaram tudo. Aí vieram começaram a queimar a casa do Jairo lá. Aí vieram descendo, descendo, queimando, quebrando.

Conforme memorando da Funai, assinado pelo administrador da regional de Roraima, encaminhado à sua Diretoria de Assuntos Fundiários, todo esse conflito foi resultado de uma decisão da direção local do Incra que resolveu proceder com o loteamento da terra, não mais como já tinha sido acordado.

É importante ressaltar que, embora tivesse ocorrido o acordo, alguns desses assentados já haviam passado por uma experiência de disputa com indígenas da Raposa/Serra do Sol, levando os assentados a adotarem uma postura mais agressiva contra os indígenas do Lago da Praia. Como os indígenas do Lago da Praia não tinham uma experiência de conflito mais intensa na qual poderia se disputar com mais equilíbrio, esta vivência acabou sendo um tanto traumática.

Muitos desses assentados adentravam na área da comunidade fazendo barulho com suas motos, assustando as mulheres e crianças quando seus esposos saíam para caçar ou pescar.

Tia Gercina: Na hora que a gente ia comer, parece que eles faziam para a gente não comer, para a gente não ir pescar, parece que era fraco, né, quando a gente estava sentando para comer, aí vem aquelas motos, carros, fazendo barulho e era buzinando e era a moto era aquela, aqueles carros, motos. Como é que chama? Aqueles "torbal" né, aquela descarga "torbal", não sei quantas motos, mas fazia era medo, sei lá, aí passava até fome a gente não come a mesma não; Aí também lá no Zé, né, passava no Zé e ia até lá em casa, lá fazer aquela volta assim e voltava de novo ficava até na beira do rio no Cláudio e voltava de novo aquela armação. Aí chegava lá e dizia "E aí vocês não vão não? Tem caminhão aí está pronto, se vocês quiserem levar suas coisas o caminhão está pronto" desse jeito; ai "ei pode ficar lá não entra não, nossa casa era cercada, né. Não entra não, pelo amor de Deus" a gente dizia, né, "não entra não, porque nós não estávamos incomodando, vocês não, vocês não essa essas vocês estão só outras essas mulheres aí porque 
eu era lá em casa com as filhas do Zé, né, e a Jacira com as filhas dela, né. E às vezes um Zé com Leôncio ficavam por aí andando, só encontrava a gente. Aí estava fazendo medo mesmo, estavam fazendo medo mesmo; aí o Zé, "rapaz, eu não sei não eu não sei não, mano, mas eu vou matar uma peste desses", ele disse né; "Eu vou matar uma peste desse, eu custo me zangar. Se eu soubesse que essas, que essas pestes, esses bando corresse daqui, se fosse correr daqui eu não tinha vindo".

A partir de então, os assentados começaram a pressionar os indígenas para que eles deixassem suas casas e voltassem para as outras comunidades. Muitos acabaram por sair de suas casas à noite para evitar qualquer tipo de confronto. Estavam fugindo de suas próprias casas, deixando para trás seus bens: roupas, panelas, suas plantações e até os documentos.

Tio Assis: É por causa do, já era do Bamerindus, né, essa área do Bamerindus, que o Bixara usou isso aí tudinho, ai disse "rapaz, esse aqui é nosso", ainda não está, aí tomaram essa decisão. Tomaram não, primeiro que tomaram a decisão de ganhar aquele, porque ainda é tempo isso. Por isso foram para ver se ganhava sabe. Mas enquanto isso, como é que diz, mas já era sim do Bamerindus, sabe, porque uma casa bem aqui no Santa Rita, no Muxinga, do outro lado, tinha uma casa, tinha um caminho que ia direto para a casa lá do Bixara, vaqueiro. Ai lá estava seu Orlando, Marcelo, sabe, ficava lá, né. Então nós vamos ganhar tudinho esse aí, fizemos como fosse para ganhar isso aí. Mas não teve jeito, perdimos tudo. Mas foram tarde já, né, não era pra... Mas foi bom mesmo do tuxaua primeiro, mas não, era para a gente ficar logo lá, antes da demarcação. Aí Lago da Praia acabou.

Em agosto de 2009, só restava a família do Tuxaua Leôncio na comunidade Lago da Praia. As outras já tinham fugido de canoa pelo rio Uraricoera ou de bicicleta, atravessando as plantações de Acácias. Alguns indígenas da comunidade Morcego e Serra do Truarú tinham ido até a comunidade Lago da Praia para tentar ajudar os parentes a permanecerem em suas casas, mas não foi o suficiente. No dia 9 de agosto, enquanto ocorria o evento em comemoração ao "Dia dos Pais" na Serra do Truarú, foi recebida a notícia de que os últimos indígenas que haviam permanecido no Lago da Praia tinham sido pegos pelos assentados a mando de algum empresário plantador de arroz e que eles só seriam liberados se os indígenas fossem embora e deixasse a terra. Assim, após muita tensão, por volta das 18 horas, os indígenas chegaram a pé no centro comunitário da Serra do Truarú, anunciando que a comunidade Lago da Praia tinha acabado. 
Em 18 de janeiro de 2010, o estado de Roraima, na época representado pelo governador José de Anchieta Junior, que veio a falecer em 2018, logo após ter perdido as eleições ocorridas dois meses antes, mostrava-se contrário à ampliação da Terra indígena Serra da Moça, até porque a demarcação da terra indígena Raposa/Serra do Sol tinha representado uma derrota para os interesses da elite do estado de Roraima e o pensamento daquele período era de que não se poderia ser destinado nenhum centímetro a mais para os povos indígenas.

A ação movida pelo estado tinha como embasamento as 19 "condicionantes" impostas pelo STF quando demarcou a terra indígena Raposa Serra do Sol, reforçando a "condicionante" 17, que veda qualquer ampliação de terras indígenas já demarcada.

Ainda nesta ação, é afirmado que o Incra, mesmo responsável por promover a reforma agrária e que deveria executar o Projeto de Assentamento Rural Nova Amazônia/Truarú, teria admitido a "invasão" de indígenas na área. O governador Anchieta finalizava dizendo que a reforma agrária não contemplava os indígenas, isto é, conforme havia sido proposto ao Tuxaua Jaime, devido à demora da demarcação, seriam loteadas terras para as famílias do Lago da Praia, mas essas terras não deveriam ser destinadas às famílias indígenas.

Logo após a ação do governo, 10 dias para ser exato, o ministro Gilmar Mendes assinou uma Ação Cautelar no dia 29 de janeiro de 2010, em que afirma que não competia ao estado de Roraima "decidir quais são os possíveis participantes dos assentamentos patrocinados pelo Governo Federal" e que "a condição de indígenas não os torna, como quer o autor, aprioristicamente inelegíveis a tais políticas públicas".

A Ação Cautelar assinada pelo ministro Gilmar Mendes, mostrando a "agilidade" do sistema judiciário brasileiro, é descrita aparentemente apenas a partir de informações disponibilizada pelo governador Anchieta e pela mídia local, tendo sido decidido o seguinte em relação à situação:

Ante o exposto, defiro o pedido de medida liminar tão-somente para garantir a manutenção dos assentamentos já realizados na referida área (Assentamento Nova Amazônia), vedando-se o acesso de novos grupos indígenas ao local. Determino, ainda, que a União e a Funai se abstenham de praticar quaisquer atos no sentido de reconhecer a referida área como terra indígena. (MEDIDA CAUTELAR EM AÇÃO CAUTELAR 2.541, Roraima).

A decisão, embora fosse apenas uma liminar, teve um resultado que causou um desânimo muito grande nos indígenas do Lago da Praia, pois, após saírem de 
suas casas, expulsos, esperaram poder retornar logo após a decisão do STF. No entanto a decisão de Gilmar Mendes decidindo por manter apenas o assentamento, mesmo que temporário, acabou impedindo o retorno ao Lago da Praia.

\section{CAMINHOS A SEREM SEGUIDOS: O SONHO NÃO ACABOU}

As discussões acerca do conjunto de "condicionantes" referentes ao caso da Terra Indígena Raposa/Serra do Sol, apresentadas pelo STF, especificamente pelo ministro Carlos Alberto Menezes Direito, como condições para sua demarcação, representaram uma afronta aos direitos dos povos indígenas e demais Comunidades e Povos Tradicionais, não considerando, portanto, que essas terras foram alvo de invasões e usurpações por parte de fazendeiros, posseiros, entre outros antagonistas dos povos indígenas.

Além de representarem um insulto a diversos instrumentos jurídicos, como a própria Constituição Federal, desconsideraram um dos instrumentos de luta mais importantes desses povos, a Convenção 169 da Organização Internacional do Trabalho (OIT), quando o ministro anteriormente citado, em seus pronunciamentos, admitiu as instalações de bases, unidades e postos militares, a atuação das Forças Armadas e da Polícia Federal e a instalação de equipamentos públicos e construções, inclusive de estradas, na terra indígena, sem a necessidade de consulta às comunidades que ali vivem (ALMEIDA; DOURADO, 2013).

Embora o ministro Gilmar Mendes tenha se valido de tais "condicionantes" para fundamentar sua Ação Cautelar e acabar com a comunidade Lago da Praia no ano de 2010, somente em 2012, é que o maior golpe contra o direito à consulta e autodeterminação dos povos e comunidades tradicionais foi feito pelo Poder Executivo. A Advocacia-Geral da União (AGU) publicou a Portaria n. 303, em junho de 2012, sob pretexto de dispor sobre as salvaguardas institucionais a terras indígenas. Esta Portaria nada mais foi do que uma forma de tornar regra geral tais "condicionantes", fazendo com que fosse submetidos todos os procedimentos de demarcação de terras indígenas, sejam aqueles que estavam em andamento, sejam aqueles já finalizados, representando, portanto, para a comunidade Lago da Praia, o enfraquecimento do sonho de ter suas terras de volta, mesmo que tais "condicionantes" representem uma afronta direta aos direitos humanos (ALMEIDA; DOURADO, 2013) e uma compreensão atrasada dos estudos antropológicos sobre as dinâmicas de transformações dos territórios tradicionalmente ocupados. 
Embora enfraquecido, retomar a comunidade Lago da Praia nunca foi um sonho deixado de ser lembrado pelos que tinham saído de lá e pelo restante das comunidades da terra indígena Serra da Moça. Em março de 2018, quase 10 anos depois da expulsão, na semana do Acampamento Terra Livre (ATL), as lideranças da Serra da Moça, junto ao CIR e sua assessoria jurídica, na época Joênia Wapichana, levaram como uma das pautas do Movimento Indígena do estado de Roraima, ainda, a ampliação da terra indígena Serra da Moça.

No entanto, no dia 28 de setembro do mesmo ano, o ministro Gilmar Mendes assinou uma nova Ação Cautelar, mais uma vez impedindo que fosse ampliada a terra indígena. E ainda, na Ação Cautelar, que na anterior dizia que não competiria a esta Corte decidir os rumos de uma área que estava sob "posse" da União, agora ele dizia o seguinte:

Desse modo, tem o Estado de Roraima legitimidade e interesse de agir nesta demanda, visando participar de processo de demarcação de reserva indígena, ainda que inserida em área de propriedade da União, bem ainda discutir judicialmente eventual ampliação daquela. (SUPREMO TRIBUNAL FEDERAL STF - AÇÃO CÍVEL ORIGINÁRIA: ACO 0001274-61.2010.1.00.0000 RR RORAIMA 0001274-61.2010.1.00.0000).

Vale lembrar que a atual gestão governamental do estado de Roraima pertence ao Partido Social Liberal (PSL), que teve como integrante o presidente do Brasil, o qual já realizou diversas declarações contra os direitos dos Povos Indígenas e demais comunidades tracionais.

Parece que fica cada dia mais impossível retornar à comunidade Lago da Praia e recuperar o que um dia foram as terras dos indígenas da Serra da Moça. De todos os lados, parece não haver apoio para que ocorra a ampliação. Tanto o governo estadual quanto os demais órgãos que deveriam defender os direitos dos povos indígenas parecem fazer pouco caso, tanto que, até os dias de hoje, nunca foi feito nenhum estudo que demostre a real realidade destas comunidades.

Tia Gercina: E é muito impossível dizer assim voltar para lá, como naquela época, né, aquela época não volta mais. Se for, vem outros. Porque a gente não teve apoio, segurança dos governantes, eles falavam uma coisa, falavam outra coisa, mas não podiam fazer nada por nós porque eles estavam, eles eram contra nós.

A fala da tia Gercina demonstra que, embora tenha essa vontade de retornar para o Lago da Praia, a falta de apoio e de segurança é desanimadora. O 
sentimento que surge em suas falas o tempo todo revela, ao mesmo tempo, que esta parte de sua história está marcada para sempre na sua vida de liderança. E, como ela afirma, "eles eram contra nós": "eles" são desde os políticos locais às autoridades da Justiça brasileira, que não buscam realmente se esforçar para entender a realidade dos povos indígenas.

Estes escritos são um pouco da história.

\section{REFERÊNCIAS}

ALEIXO WAPICHANA, Eriki. Sociogênese da mobilização étnica ocorrida na comunidade Serra do Truarú (Terra Indígena Serra da Moça, etnoregião Murupú, Boa Vista-RR). Horizontes Antropologicos, v. 26, n. 58, 2020. [no prelo].

ALMEIDA, Alfredo Wagner Berno; DOURADO, Sheilla Borges. Apresentação In: ALMEIDA, Alfredo Wagner Berno et al. Consulta e participação prévia: a crítica à metáfora da teia de aranha. Manaus: UEA Edições; PPGSA/PPGAS/Ufam, 2013.

CASTRO FARIA, Luiz de. A Antropologia no Brasil. Depoimento sem Compromissos de um Militante em Recesso. Anuário Antropológico, Brasil, n.7, v.1, p. 228-50, 1983.

FARAGE, Nádia; SANTILLI, Paulo. Estado de Sítio: territorialidade e identidade no vale do Rio Branco: In: CUNHA, Manuela Carneiro (Org.). História dos índios no Brasil. São Paulo: Fapesp, Companhia das Letras; Secretaria Municipal de Cultura, 1992.

FARAGE, Nádia. As muralhas do Sertão- os povos indígenas no rio Branco e a Colonização. 1986. Dissertação (Mestrado em Antropologia Social) - Universidade de São Paulo, São Paulo, SP, 1986.

OLIVEIRA FILHO, João Pacheco. Regime tutelar e faccionalismo - política e religião em uma reserva Ticuna. Manaus: UEA Edições, 2015.

REPETTO, Maxim. Movimentos indígenas e conflitos territoriais no estado de Roraima. Boa Vista: Editora da UFRR, 2008.

RIBEIRO, Gilmara Fernandes. Criadores de gado: experiência dos Macuxi com o gado bovino. Dissertação (Mestrado em Antropologia) - Departamento de Antropologia, Universidade Federal de Roraima, Boa Vista, RR, 2018.

SANTILLI, Paulo. Pemongon Patá - território Macuxi: rotas de conflito. Petrópolis: Vozes, 2001. 
VIEIRA, Jaci Guilherme. Missionários, fazendeiros e índios em Roraima: a disputa pela terra - 1777 a 1980. 2003. Tese (Doutorado em História) - Universidade Federal de Pernambuco, 2003.

\section{Documentos consultados}

PROCESSO N. 28870.000919/1981 - 68 - Identificação da área indígena Serra da Moça.

PROCESSO N. 28870.002054.1989-21 - Homologação da TI Serra da Moça.

Dossiê Terra Indígena Serra da Moça- Lago da Praia/CIR.

MEDIDA CAUTELAR EM AÇÃO CAUTELAR 2.541 RORAIMA. Disponível em: https://www. conjur.com.br/dl/decisao-gilmar-mendes-invasao-indigena.pdf. Acesso em: jul. 2019.

SUPREMO TRIBUNAL FEDERAL (STF). AÇÃO CÍVEL ORIGINÁRIA: ACO 0001274 61.2010.1.00.0000 RR- RORAIMA 0001274-61.2010.1.00.0000. Disponível em: https:// stf.jusbrasil.com.br/jurisprudencia/782985515/acao-civel-originaria-aco-1522-rrroraima-0001274-6120101000000. Acesso em: jul. 2019.

\section{Entrevistas}

Entrevista com dona Carminha e Tuxaua Jaime, Macuxi, moradores da Comunidade Morcego. Morcego, região Murupú, Município de Boa Vista, RR, em abril de 2016.

Entrevista com Francisco de Assis Aleixo Angelo, Wapichana, morador da Comunidade Serra do Truarú. Serra do Truarú, região Murupú, Município de Boa Vista, RR, em abril de 2016.

Entrevista com Geovânia Angelo Aleixo, Wapichana, moradora da Comunidade Serra do Truarú. Serra do Truarú, região Murupú, Município de Boa Vista, RR, em abril de 2016.

Entrevista com Gercina Angelo da Silva, Wapichana, moradora da Comunidade Serra do Truaru. Serra do Truarú, Etnorregião Murupú, Município de Boa Vista, RR, em abril de 2016.

Entrevista com Gercina Angelo da Silva, Wapichana, moradora da Comunidade Serra do Truarú. Serra do Truarú, Etnorregião Murupú, Município de Boa Vista, RR, em setembro de 2018.

Entrevista com Lenice Nagelo da Silva, Wapichana, moradora da Comunidade Morcego, Etnorregião Murupú, Município de Boa Vista, RR, em abril de 2016. 
Entrevista com Leôncio Lourenço da Silva, Wapichana, morador da Comunidade Serra do Truarú. Serra do Truarú, Etnorregião Murupú, Município de Boa Vista, RR, em setembro de 2018.

\section{Sobre o autor:}

Eriki Aleixo de Melo: Indígena Wapichana, morador da comunidade Serra do Truarú. Doutorando e mestre em Antropologia Social pela Universidade Federal do Amazonas (PPGAS/Ufam). Graduado em História pela Universidade Federal de Roraima (UFRR). Pesquisador do Projeto Nova Cartografia Social da Amazônia (PNCSA). Membro da Articulação Brasileira de Indígenas Antropologes (ABIA). E-mail: eriki.aleixo@hotmail.com, Orcid: http://orcid.org/0000-0002-2658-3027

Recebido em: 9 de janeiro de 2020.

Aprovado para publicação em 22 de maio de 2020. 